University of Nebraska - Lincoln

DigitalCommons@University of Nebraska - Lincoln

\title{
Development of the California Current during the past 12,000 yr based on diatoms and silicoflagellates
}

John A. Barron

MS 910, U.S. Geological Survey, Menlo Park, CA 94025, USA

David Bukry

MS 910, U.S. Geological Survey, Menlo Park, CA 94025, USA

Follow this and additional works at: https://digitalcommons.unl.edu/usgsstaffpub

Part of the Earth Sciences Commons

Barron, John A. and Bukry, David, "Development of the California Current during the past 12,000 yr based on diatoms and silicoflagellates" (2007). USGS Staff -- Published Research. 262.

https://digitalcommons.unl.edu/usgsstaffpub/262

This Article is brought to you for free and open access by the US Geological Survey at DigitalCommons@University of Nebraska - Lincoln. It has been accepted for inclusion in USGS Staff -- Published Research by an authorized administrator of DigitalCommons@University of Nebraska - Lincoln. 


\title{
Development of the California Current during the past 12,000 yr based on diatoms and silicoflagellates
}

\author{
John A. Barron *, David Bukry \\ MS 910, U.S. Geological Survey, Menlo Park, CA 94025, USA
}

Received 3 July 2006; received in revised form 6 December 2006; accepted 13 December 2006

\begin{abstract}
Detailed diatom and silicoflagellates records in three cores from the offshore region of southern Oregon to central California reveal the evolution of the northern part of the California Current during the past 12,000 yr. The early Holocene, prior to $\sim 9 \mathrm{ka}$, was characterized by relatively warm sea surface temperatures (SST), owing to enhanced northerly flow of the subtropical waters comparable to the modern Davidson Current. Progressive strengthening of the North Pacific High lead to intensification of the southward flow of the California Current at $\sim 8 \mathrm{ka}$, resulting in increased coastal upwelling and relatively cooler SST which persisted until $\sim 5 \mathrm{ka}$. Reduced southward flow of the California Current between $\sim 4.8 \mathrm{ka}$ and 3.6 ka may have been responsible for a period of decreased upwelling. Modern seasonal oceanographic cycles, as evidenced by increased spring-early summer coastal upwelling and warming of early fall SST evolved between 3.5 and $3.2 \mathrm{ka}$. Widespread occurrence of paleoceanographic and paleoclimatic change between $\sim 3.5-$ $3.0 \mathrm{ka}$ along the eastern margins of the North Pacific was likely a response to increasing ENSO variability in the tropical Pacific.

Published by Elsevier B.V.
\end{abstract}

Keywords: Holocene; California; Upwelling; Diatom; Silicoflagellates; ENSO

\section{Introduction}

\subsection{Setting}

Waters off the coasts of northern California and southern Oregon lie near the modern-day boundary between the subarctic and subtropical gyres of the North Pacific, where they are influenced by the strength and character of the California Current (Huyer, 1983). The California Current begins at the divergence of the West Wind Drift, which lies between about $42^{\circ}$ and $50^{\circ} \mathrm{N}$ along the western margin of North America (Fig. 1). During much of the spring and summer, juxtaposition of the North

\footnotetext{
* Corresponding author.

E-mail address: jbarron@usgs.gov (J.A. Barron).
}

Pacific High and the North American Low results in strong, persistent northwesterly winds which induce coastal upwelling and lead to high biologic productivity (Hood et al., 1999). Winters are influenced by a weakened North American Low, the southward migration of the North Pacific High from $\sim 40^{\circ} \mathrm{N}$ to $\sim 30^{\circ} \mathrm{N}$, and the southward migration of the jet stream (from $\sim 48^{\circ} \mathrm{N}$ to an average position of $38^{\circ} \mathrm{N}$ ) due to a strengthening of the Aleutian Low (Fleming et al., 1987: Bograd et al., 2002). Winters are typically mild, wet, and stormy, with southwesterly winds and a noticeable lack of upwelling (Huyer, 1983).

Bolin and Abbott (1962), Huyer (1983), and Strub et al. (1987) emphasize the major regional differences in seasonal cycles of currents, sea surface temperature (SST), winds and sea level along the North American coast between $33^{\circ} \mathrm{N}$ and $48^{\circ} \mathrm{N}$. During the late winter, 
northwest winds steadily increase as offshore Ekman transport results in coastal upwelling. Surface water salinity increases with upwelling reaching its maximum in June and July. September and October bring a period of calm, as the northwest winds diminish. Cold surface water sinks, replaced by warmer offshore surface waters from the Central Gyre. Beginning in November, southerly winds of the winter help to initiate the Davidson Current, a northward flowing coastal current that typically is active through February. Although SST declines during this winter period, subsurface water $(\sim 50 \mathrm{~m})$ increases in temperature as a result of a northward flowing undercurrent. Thus, a deep thermocline characterizes the winter.
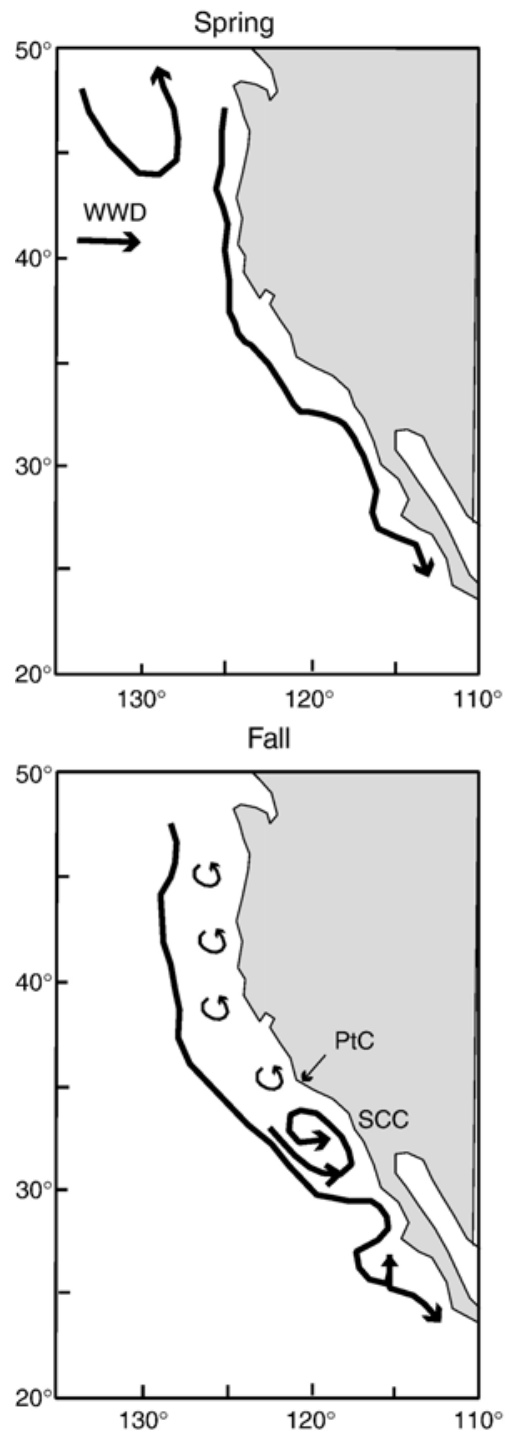

Strub et al. (1987) stress that the magnitudes of the seasonal cycles of all variables are at a maximum between about $38^{\circ} \mathrm{N}$ and $43^{\circ} \mathrm{N}$ (northern California to southern Oregon), implying a strong sensitivity to climatic cycles such as El Niño-Southern Oscillation (ENSO). Paleoceanographic studies in the northern part of the California Current region off southernmost Oregon and northern California should help to resolve the evolution of Holocene evolution of these seasonal cycles.

\subsection{Previous paleoclimate studies}

The majority of paleoclimate studies from offshore California and Oregon have concentrated on estimating
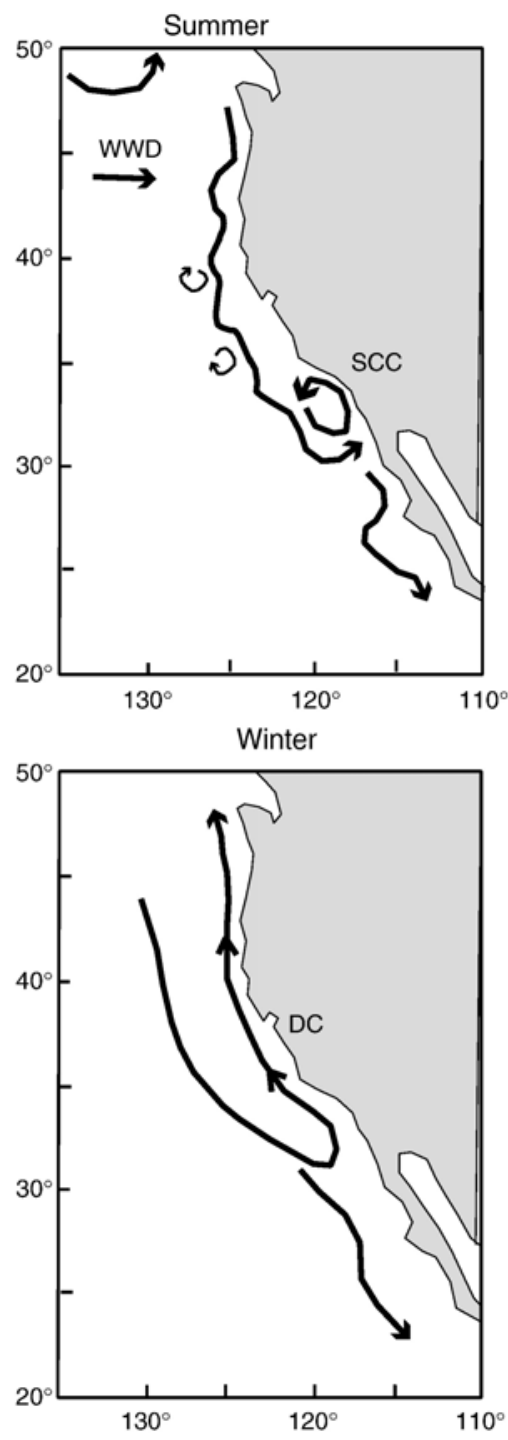

Fig. 1. Seasonal circulation of the California Current modified from P.T. Strub (unpub.). WWD = West Wind Drift; SCC $=$ Southern California Countercurrent; PtC = Pt. Conception; DC = Davidson Current. http://globec.oce.orst.edu/groups/nep/reports/ebcip/ebcip.physsetting.html. 
the amount of sea surface temperature (SST) change between the last glacial maximum (LGM) and the present (Kiefer and Kienast, 2005). Estimates of SST change between the LGM and the present based on oxygen isotopes of planktonic foraminifers have ranged from 5 to $7{ }^{\circ} \mathrm{C}$ off southern California (south of Point Conception at $34.5^{\circ} \mathrm{N}$ ) (Kennett and Ingram, 1995: Mortyn et al., 1996; Hendy and Kennett, 2000), to 2 to $3{ }^{\circ} \mathrm{C}$ off northern California and southern Oregon (Ortiz et al., 1997; Mix et al., 1999). Estimates of LGMpresent SST change using alkenones have been typically lower in the south $\left(\sim 2\right.$ to $\left.3{ }^{\circ} \mathrm{C}\right)$ than those in the north $\left(\sim 4\right.$ to $5^{\circ} \mathrm{C}$ ) (Herbert et al., 1995; Prahl et al., 1995; Doose et al., 1997; Kreitz et al., 2000; Barron et al., 2003).

Few of these studies have dealt with SST change occurring during the Holocene (Kim et al., 2004; Kiefer and Kienast, 2005). Kim et al. (2004) summarize Holocene alkenone studies in the North Pacific, concluding that the alkenone data indicate a SST increase over the entire North Pacific during the past $7000 \mathrm{yr}$ with an abrupt transition in the northeastern Pacific towards warmer SST between 4 and 3 ka. Throughout this paper "ka" refers to calendar kyr before present.

Sabin and Pisias (1996) made radiolarian-based SST reconstructions for the waters ranging in latitude from $33.6^{\circ}$ to $54.4^{\circ} \mathrm{N}$ for the past $15,000 \mathrm{yr}$ in 12 well-dated deep-sea cores. The reconstructions of Sabin and Pisias (1996) revealed regional differences in both deglacial SST changes and SST variations within the Holocene. Between 20.0 and $10.0 \mathrm{ka}$, they suggested that the deglacial SST change was about +2 to $3{ }^{\circ} \mathrm{C}$ in the south (between $33^{\circ}$ and $36^{\circ} \mathrm{N}$ ), but rose in the north to $+4^{\circ} \mathrm{C}$ between $37^{\circ}$ and $43^{\circ} \mathrm{N}$, comparable to estimates made using alkenones. Within the Holocene, they predicted SST variations of $\sim 1$ to $2{ }^{\circ} \mathrm{C}$ in the region between $33^{\circ}$ and $36^{\circ} \mathrm{N}$, increasing to $\sim 2^{\circ} \mathrm{C}$ within the region between $37^{\circ}$ and $43^{\circ}$ N. Sabin and Pisias (1996) reported that maximum SSTs occurred at $\sim 10.0 \mathrm{ka}$ within both the northern and southern regions. Their reconstructions, however, suggested that the middle part of the Holocene ( $\sim 8.0$ to $5.0 \mathrm{ka})$ was the coolest period (by 1 to $2{ }^{\circ} \mathrm{C}$ ) of the Holocene in the northern region between $37^{\circ}$ and $43^{\circ} \mathrm{N}$.

Mix et al. (1999) measured the $\delta^{18} \mathrm{O}$ of Neogloboquadrina pachyderma, a planktic foraminifer inhabiting intermediate water depths (Friddell et al., 2003), at ODP Site $1019\left(41.682^{\circ} \mathrm{N}, 124.930^{\circ} \mathrm{W}, 980 \mathrm{~m}\right.$ water depth) (Fig. 2). Their results showed relatively large climatic oscillations during the last deglaciation, including Younger Dryas values that were about 0.5 to $0.8 \%$ o

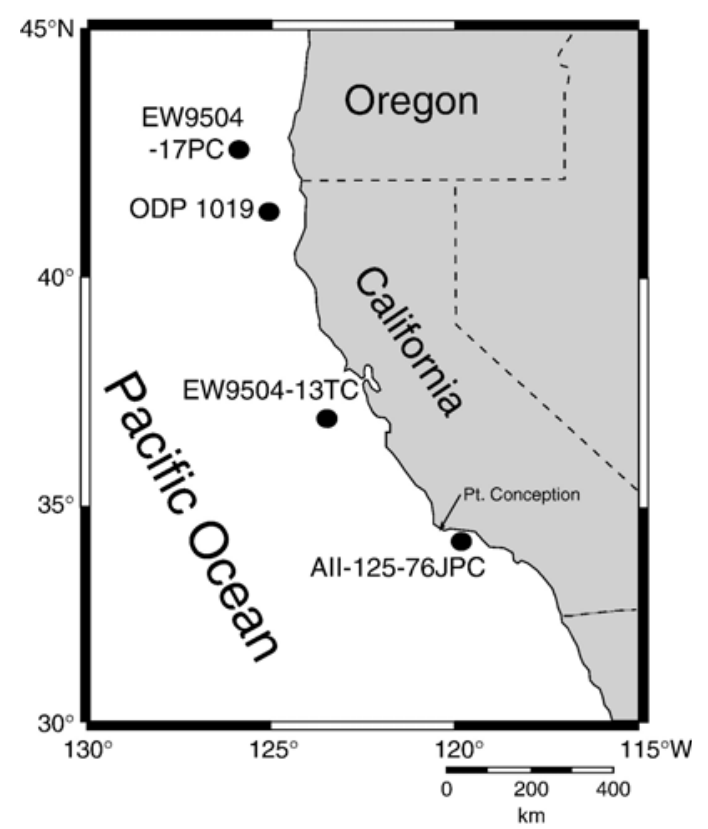

Fig. 2. Map of the Pacific margins of California and Oregon showing the locations of cores studied or mentioned.

greater (or $2-3{ }^{\circ} \mathrm{C}$ cooler if they are entirely due to temperature) than the intervals immediately preceding and following. Mix et al. (1999) reported a middle Holocene period of increased $\delta^{18} \mathrm{O}$ of $N$. pachyderma between $\sim 8$ and $6 \mathrm{ka}$ which separated early and late Holocene intervals of relatively decreased $\delta^{18} \mathrm{O}$ values. Increased relative numbers of right-coiling forms of $N$. pachyderma prior to $\sim 8.5$ ka suggested to Mix et al. (1999) that the early part of the Holocene was relatively warm at ODP 1019. They argued that the dominance of left-coiling forms of this planktic foraminifer after $\sim 8.0 \mathrm{ka}$ implied that subsurface conditions at ODP 1019 resembled those of the LGM.

Pisias et al. (2001) compared detailed radiolarian and pollen records for the past $60,000 \mathrm{yr}$ from two piston cores from offshore southern Oregon (W8709A-13PC and EW9504-17PC), ODP Site 1019 off northern California and piston core EW9504-13PC $\left(37^{\circ} \mathrm{N}\right)$ off central California (Fig. 2) with the GISP-2 oxygen isotope record. They argued that at wavelengths $>3000 \mathrm{yr}$, warm events in the GISP-2 oxygen isotope record of Greenland correlated with increased coastal upwelling off Oregon, a decline in very cold North Pacific radiolarian assemblages, and increases in pollen associated with wetter coastal environments. Pisias et al. (2001) observed that warming in coastal regions was due to reduced advection by the California Current, even though it was moderated by an increase in coastal 
upwelling. They inferred that SST variability in this region of the northeast Pacific during the past 150,000 yr was about $2{ }^{\circ} \mathrm{C}$.

Seki et al. (2002) published an alkenone SST record of the last $82 \mathrm{kyr}$ for ODP $1017\left(34.5^{\circ} \mathrm{N}\right)$ off Point Conception, California. These authors showed that alkenone SSTs faithfully recorded both DansgaardOeshger events and Heinrich events between $\sim 75$ and $10 \mathrm{ka}$ in a manner remarkably similar to that suggested by the $\delta^{18} \mathrm{O}$ planktonic foraminiferal studies of Kennett et al. (2000). In addition, Seki et al.'s (2002) alkenone data suggested that SSTs were $\sim 1-2{ }^{\circ} \mathrm{C}$ lower during the middle part of the Holocene ( $\sim 8$ to $4 \mathrm{ka}$ ) than they were during the earlier and later parts of the Holocene.

Barron et al. (2003) completed a high-resolution study of the paleoceanography of ODP Site 1019 using diatoms, alkenones, pollen, $\% \mathrm{CaCO}_{3}$, and total organic carbon. They showed that marine climate proxies (alkenone SST and $\% \mathrm{CaCO}_{3}$ ) behaved remarkably similar to the GISP-2 oxygen isotope record during the Bølling-Allerod, Younger Dryas (YD), and early part of the Holocene. During the YD, alkenone SST decreased by $>3{ }^{\circ} \mathrm{C}$ below mean Bølling-Allerod and Holocene SST's. The early Holocene $(\sim 11.6$ to $8.2 \mathrm{ka})$ was a time of generally warm conditions and moderate $\mathrm{CaCO}_{3}$ content (generally $>4 \%$ ). The middle part of the Holocene ( $\sim 8.2$ to $3.2 \mathrm{ka}$ ) was marked by alkenone SST that were consistently $1-2{ }^{\circ} \mathrm{C}$ cooler than either the earlier or later parts of the Holocene, similar to the alkenone results of Seki et al. (2002) at ODP 1017. Starting at $\sim 5.2 \mathrm{ka}$, coastal redwood and alder began a steady rise, arguing for increasing effective moisture and the development of the northcoast temperate rain forest. According to Barron et al. (2003), modern oceanographic and climatic conditions at ODP 1019 evolved between $\sim 3.5$ and $3.2 \mathrm{ka}$, as seasonal contrasts driven by enhanced ENSO cycles became established.

Friddell et al. (2003) published a detailed record of $\delta^{18} \mathrm{O}$ of the planktic foraminifers $N$. pachyderma and Globigerina bulloides between 11 and 3 ka from piston core Atlantis II-125-76JPC $\left(34.2^{\circ} \mathrm{N}\right)$ in the Santa Barbara Basin (SBB).(Fig. 2). A stepwise shift toward lighter $\delta^{18} \mathrm{O}$ of the near-surface dwelling $G$. bulloides at $\sim 7.6 \mathrm{ka}$ suggested to them that the SBB experienced significant warming of its surface waters which continued until $\sim 3.6 \mathrm{ka}$. Friddell et al. (2003) derived a record of thermal stratification of surface waters by subtracting the $\delta^{18} \mathrm{O}$ of deeper dwelling $N$. pachyderma, from that of the shallower dwelling G. bulloides. These authors used this $\delta^{18} \mathrm{O}$ difference index to suggest that thermal stratification of surface waters in the SBB was at its maximum between $\sim 5.2$ and $3.6 \mathrm{ka}$. Friddell et al. (2003) argued that this $\sim 5.2$ to 3.6 ka period of greater surface water stratification was due to enhanced El Niño-like conditions. After 3.5 ka, Friddell et al. (2003) observed that thermal stratification of the surface waters of SBB was greatly reduced and El Niño-like conditions diminished. The results of Friddell et al. (2003) in the SBB thus differ from those of Barron et al. (2003) off northern California in suggesting that the middle part of the Holocene was typified by warm, El Niño-like conditions rather than cool, La Niña-like conditions.

Santa Barbara Basin, however, is not in the direct path of the California Current, but is influenced by warm subtropical waters during most of the year (Fig. 1). Strong northerly winds associated with intensification of the offshore California Current induce coastal upwelling during the spring, but the summer and early fall are influenced by the Southern California Countercurrent. The northward flowing Davidson Current is active in the winter (Hendershott and Winnant, 1996; Di Lorenzo, 2003; Fig. 1).

To date, no downcore studies of the relative abundance of silicoflagellates have been published on Holocene sediments from the middle to high latitude eastern North Pacific. Studies of North Pacific surface sediments (Poelchau, 1976) and sediment traps (Takahashi, 1987; Takahashi et al., 1989; Onodera and Takahashi, 2005), however, have established the ecologic preferences of numerous silicoflagellate taxa. Silicoflagellates have proven their utility in suggesting Holocene paleotemperature and upwelling changes in the Gulf of California (Barron et al., 2004, 2005). Together, diatoms and silicoflagellate assemblages should help reveal a detailed Holocene paleoceanographic history of the northern part of the California Current.

The purpose of this paper is to use high resolution diatom and silicoflagellate assemblage data in piston core EW9504-17PC off southern Oregon, ODP 1019 off northernmost California and piston core EW9504-13TC off central California (Fig. 2) to detail the paleoceanographic history of the northern part of the California Current during the Holocene. Results will be compared with the alkenone SST data of Herbert for ODP 1019 published in Barron et al. (2003) and with other Holocene proxy SST records.

\section{Materials and methods}

Piston Core EW9504-17PC is located at $42.24^{\circ} \mathrm{N}$, $125.89^{\circ} \mathrm{W}$ at a water depth of $2671 \mathrm{~m}$ (Fig. 2). The age model used for this core is after Pisias et al. (2001) and Lyle et al. (2000). Samples taken every $5 \mathrm{~cm}$ for the 
Holocene have an age resolution between $\sim 200$ and $400 \mathrm{yr}$.

ODP 1019 is located at $41.68^{\circ} \mathrm{N}, 124.93^{\circ} \mathrm{W}$ at a water depth of $989 \mathrm{~m}$ (Fig. 2). The age model is after Barron et al. (2003). Samples taken roughly every $5 \mathrm{~cm}$ for the Holocene have an age resolution between $\sim 100$ and $200 \mathrm{yr}$.

Trigger Weight Core EW9504-13TC is located at $36.99^{\circ} \mathrm{N}, 123.268^{\circ} \mathrm{W}$ at a water depth of $2510 \mathrm{~m}$ (Fig. 2). It lies approximately $140 \mathrm{~km}$ west of Santa Cruz, California. The age model for EW9504-13PC is after Pisias et al. (2001). The top of EW9504-13PC $(0 \mathrm{~cm})$ is dated at $12.0 \mathrm{ka}$ and is correlated to the $196 \mathrm{~cm}$ interval of EW9504-13TC based on physical properties (W. Dean, 2004, written comm.). A uniform sedimentation rate of $\sim 16 \mathrm{~cm} / \mathrm{kyr}$ was used to estimate ages of samples that were taken every $2 \mathrm{~cm}$ from the top $50 \mathrm{~cm}$ (last $3 \mathrm{kyr}$ ) and every $5 \mathrm{~cm}$ through the rest of EW9504-13TC. Age resolution of samples varies from $\sim 120$ to $300 \mathrm{yr}$.

\subsection{Processing}

As explained by Barron et al. (2003), samples from ODP 1019 were disaggregated in distilled water and then processed by boiling them in 30\% hydrogen peroxide and $37 \%$ hydrochloric acid. The acid was then removed through several washings in distilled water separated by at least $4 \mathrm{~h}$ of settling and decanting away of the liquid. The final sample was stored in a vial containing at least 7-10 times as much distilled water as sample. To prepare slides, the vial was shaken and a drop of the suspension was taken after 5-10 s of settling from near the top of the vial, transferred to a $22 \times 30 \mathrm{~mm}$ cover slip and allowed to dry on a warming tray overnight. Slides were then mounted in Hyrax (index of diffraction $=1.71$ ).

Samples from EW9504-17PC and EW9504-13TC were not processed in hydrogen peroxide and hydrochloric acid. Rather, they were placed in a glass vial and covered with 7-10 times as much distilled water as sample. A disposable wooden stick was then used to disaggregate the samples in the vials by stirring the suspension. To prepare slides, the vial was shaken and a drop of the suspension was taken after 5-10 s of settling from near the top of the vial, transferred to a $30 \times 22 \mathrm{~mm}$ cover slip and allowed to dry on a warming tray overnight. Slides were then mounted in Naphrax (index of diffraction=1.74).

\subsection{Diatoms}

At least 300 individual diatoms were counted using the counting techniques of Schrader and Gersonde
(1978) by making random traverses of the slide under the light microscope at 1250X. Following Sancetta (1992) and Barron et al. (2003), Chaetoceros resting spores, which dominate in nearshore coastal upwelling environments (Lopes et al., 2006), were not counted so that differences in offshore oceanic conditions might be better resolved. Diatom abundances were estimated by recording the number of diatom valves encountered while making vertical traverses of the slide (length of traverse $=22 \mathrm{~mm}$ ) at $1250 \times$ (total area covered per traverse $=4.114 \mathrm{~mm}^{2}$ ). Random traverses were made until $>300$ diatom valves were counted. The taxonomy of Barron et al. (2003) was followed.

\subsection{Silicoflagellates}

Silicoflagellates are diluted by diatoms at EW950413TC and by coarse quartz silt and diatoms in both EW9504-17PC and ODP 1019. One to three slides were systematically tracked to obtain a representative count of 50 to 100 specimens per sample. Counts typically were made at $250 \mathrm{X}$ magnification, with $500 \mathrm{X}$ used for checking questionable specimens. All whole specimens and half specimens with intact apical structures were counted. Older intervals $(\sim 15.4 \mathrm{ka}$ to $11.5 \mathrm{ka})$ in EW9504-17PC were also consistently diluted by common to abundant coccoliths, such as Calcidiscus leptoporus, Coccolithus pelagicus and Helicosphaera carteri. Taxonomy follows that used by Bukry (1973, $1980,1981)$ for stratigraphic studies in the area with some modifications as used in Barron et al. $(2004,2005)$ for paleoceanographic studies in the Gulf of California. Intraspecific variants of silicoflagellate taxa were tabulated in an effort to determine paleoecologic preferences.

\section{Results}

\subsection{Diatoms}

The relative abundance of selected diatom taxa during the past 15,000 $\mathrm{yr}$ in cores EW9504-17PC and EW9504-13TC is shown in Tables 1 and 2.

Fig. 3 compares the percentage relative abundance records of the main diatom groups in cores EW950417PC and EW9504-13TC with that of ODP 1019 (Barron et al., 2003). The record of EW9504-17PC older than $\sim 11 \mathrm{ka}$ and the record of EW9504-13TC between $\sim 13$ and $7 \mathrm{ka}$ contain poorly preserved diatom assemblages and are not plotted, with the exception of a single sample from EW9504-13TC. 


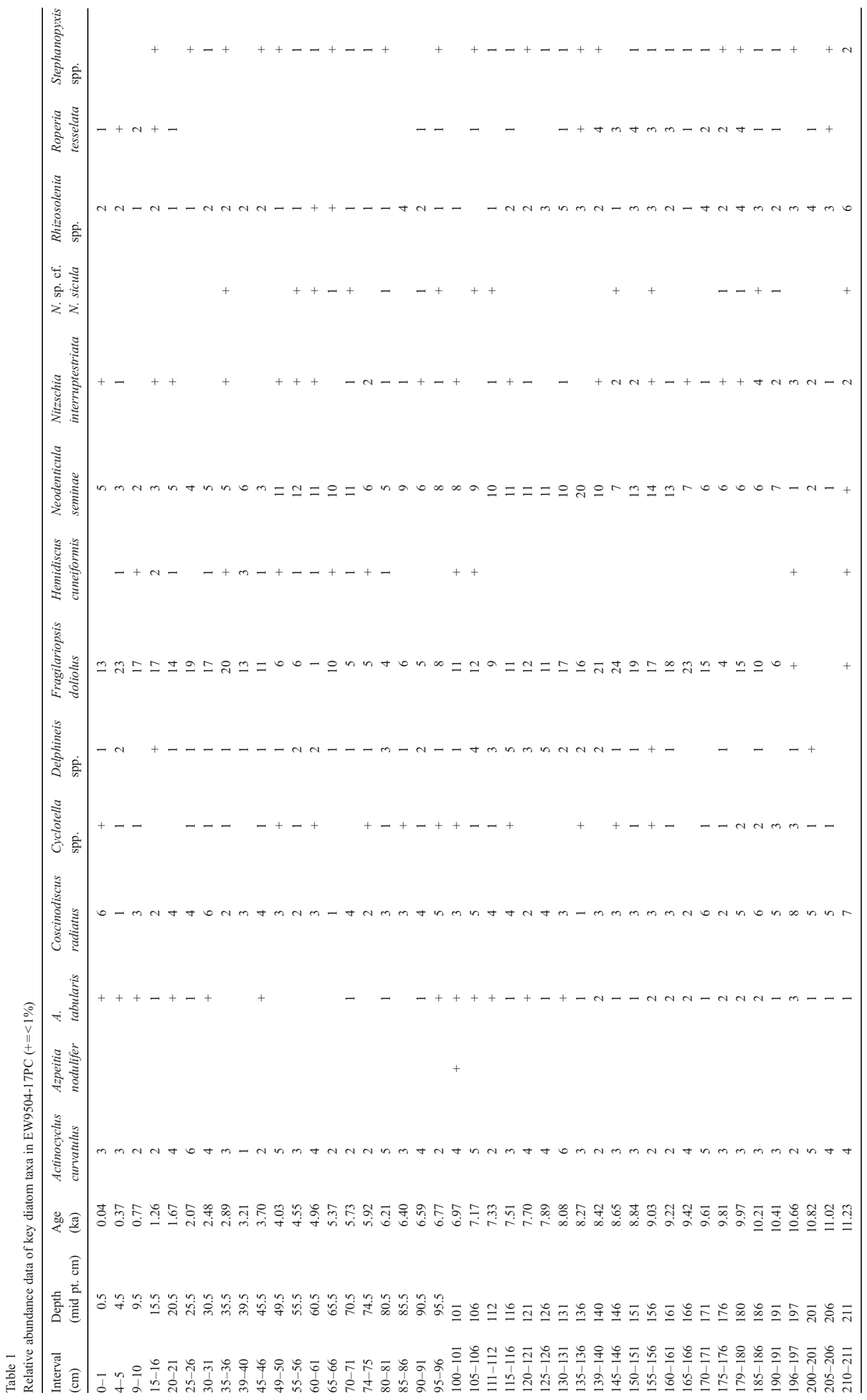




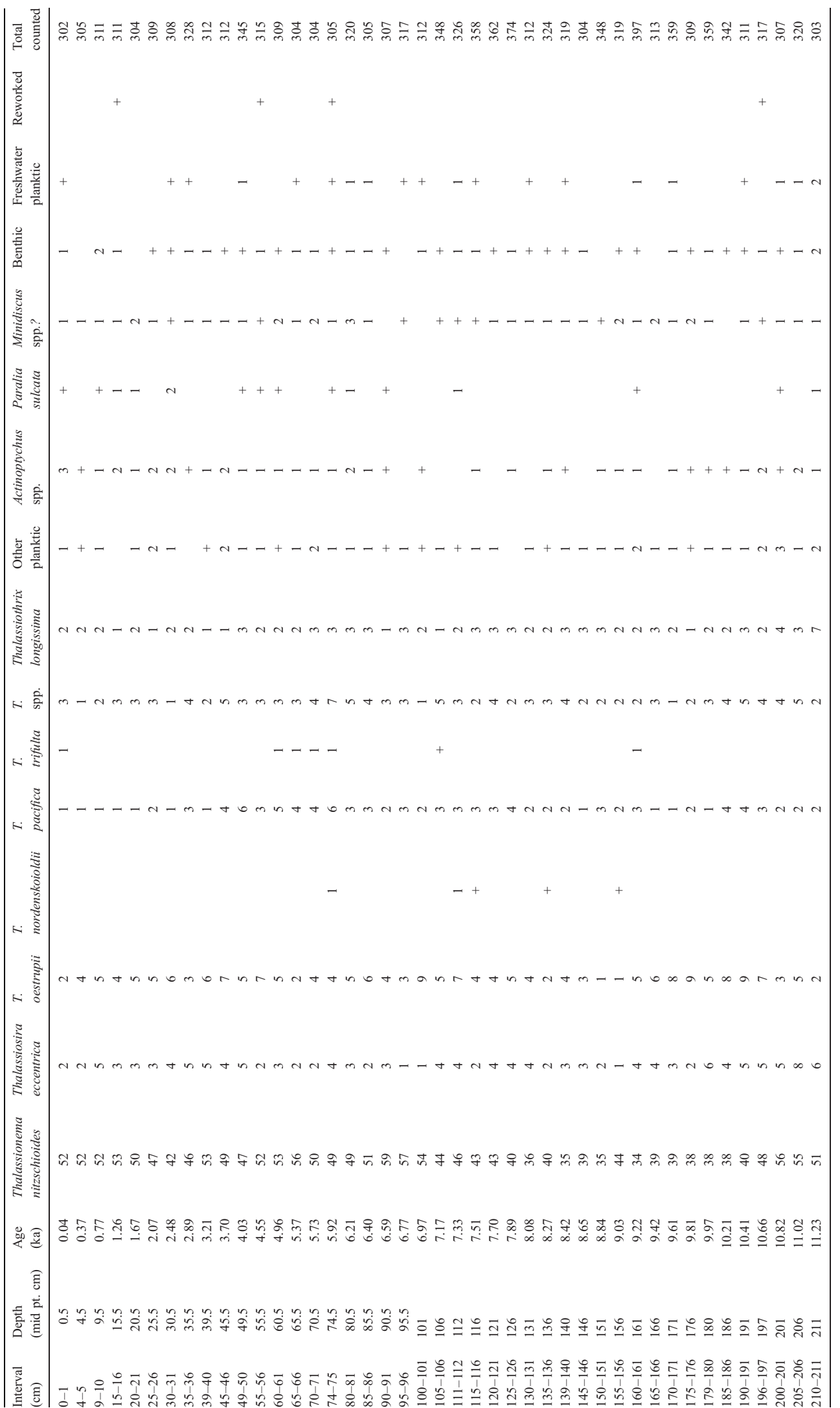




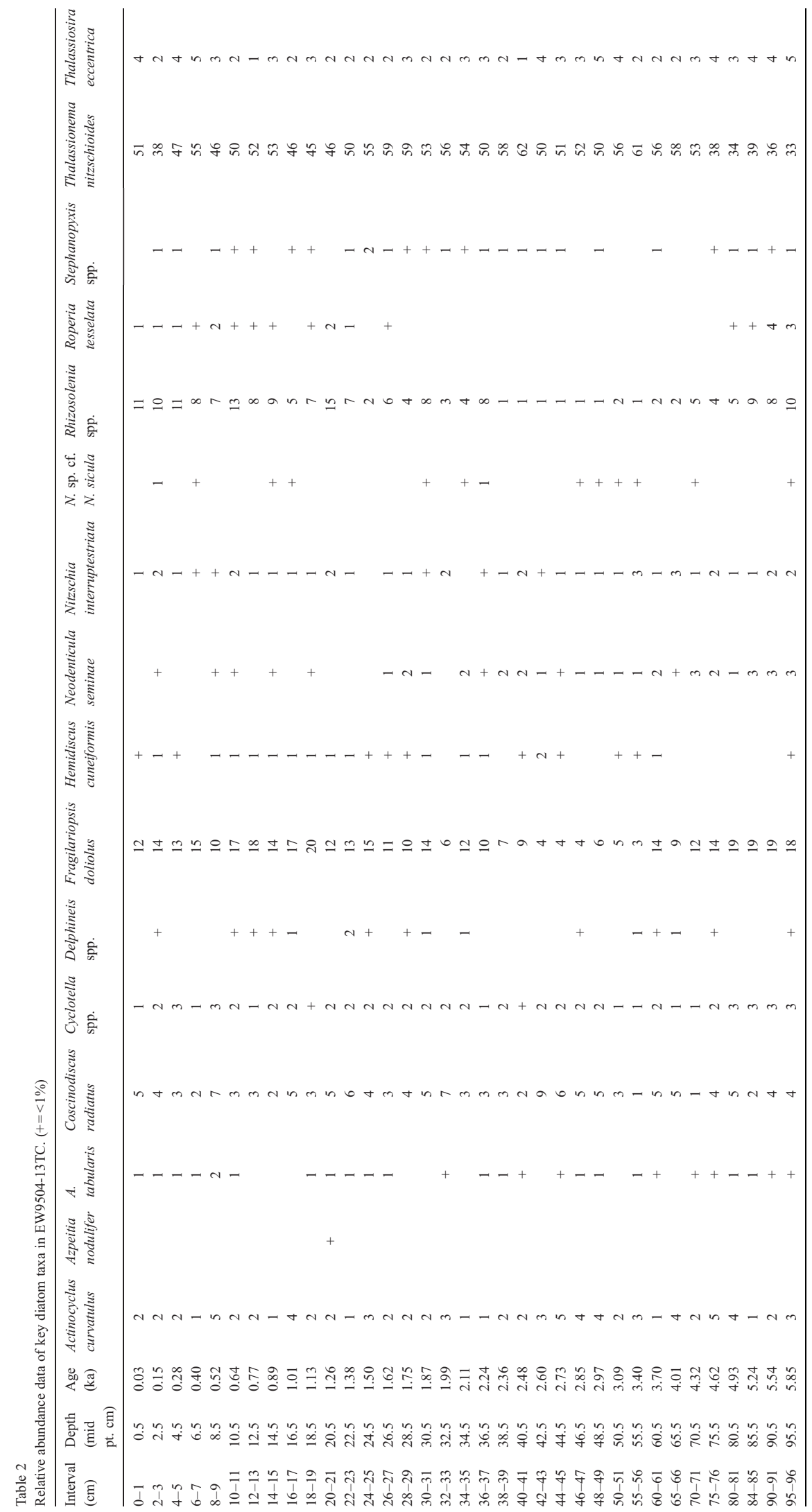




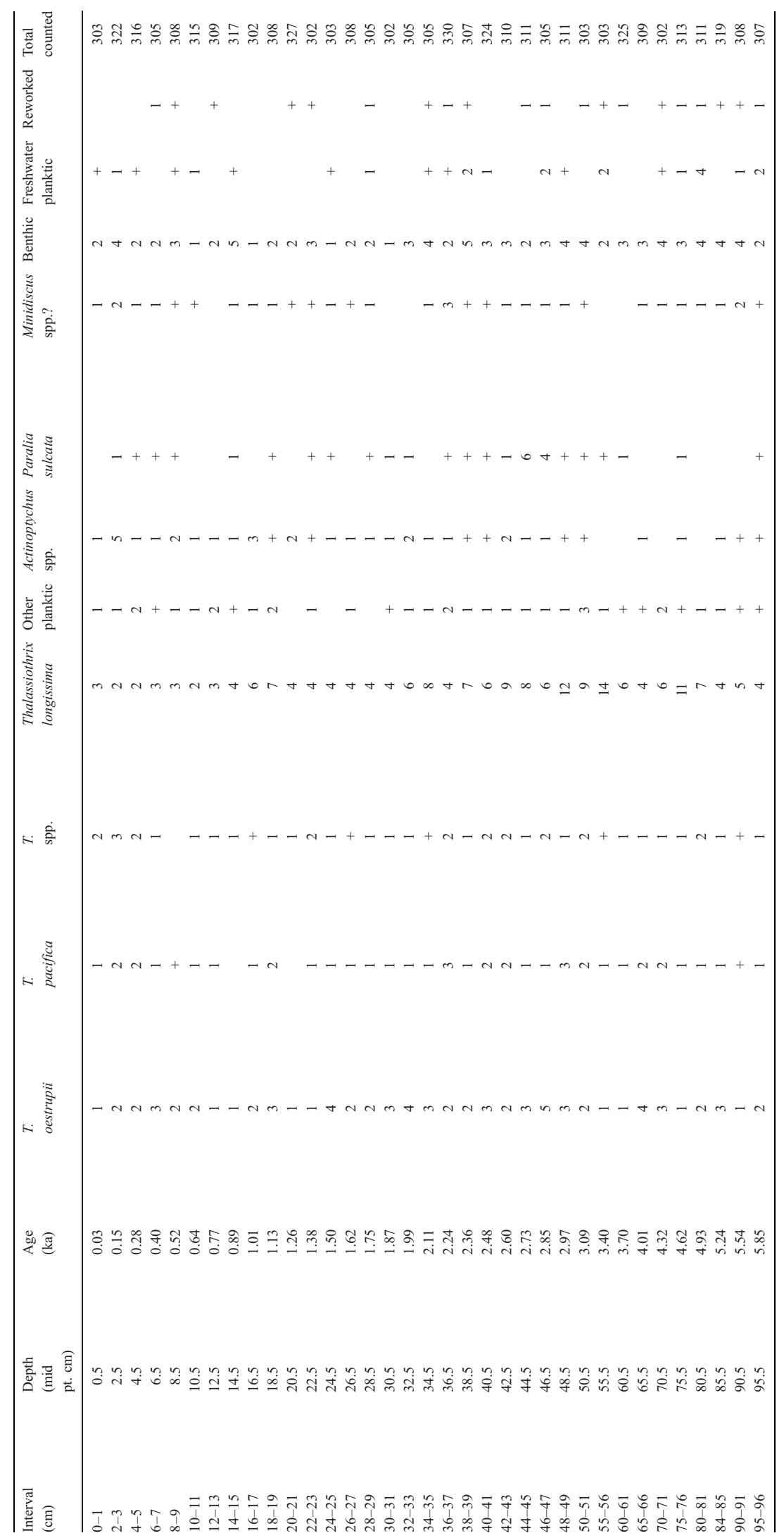




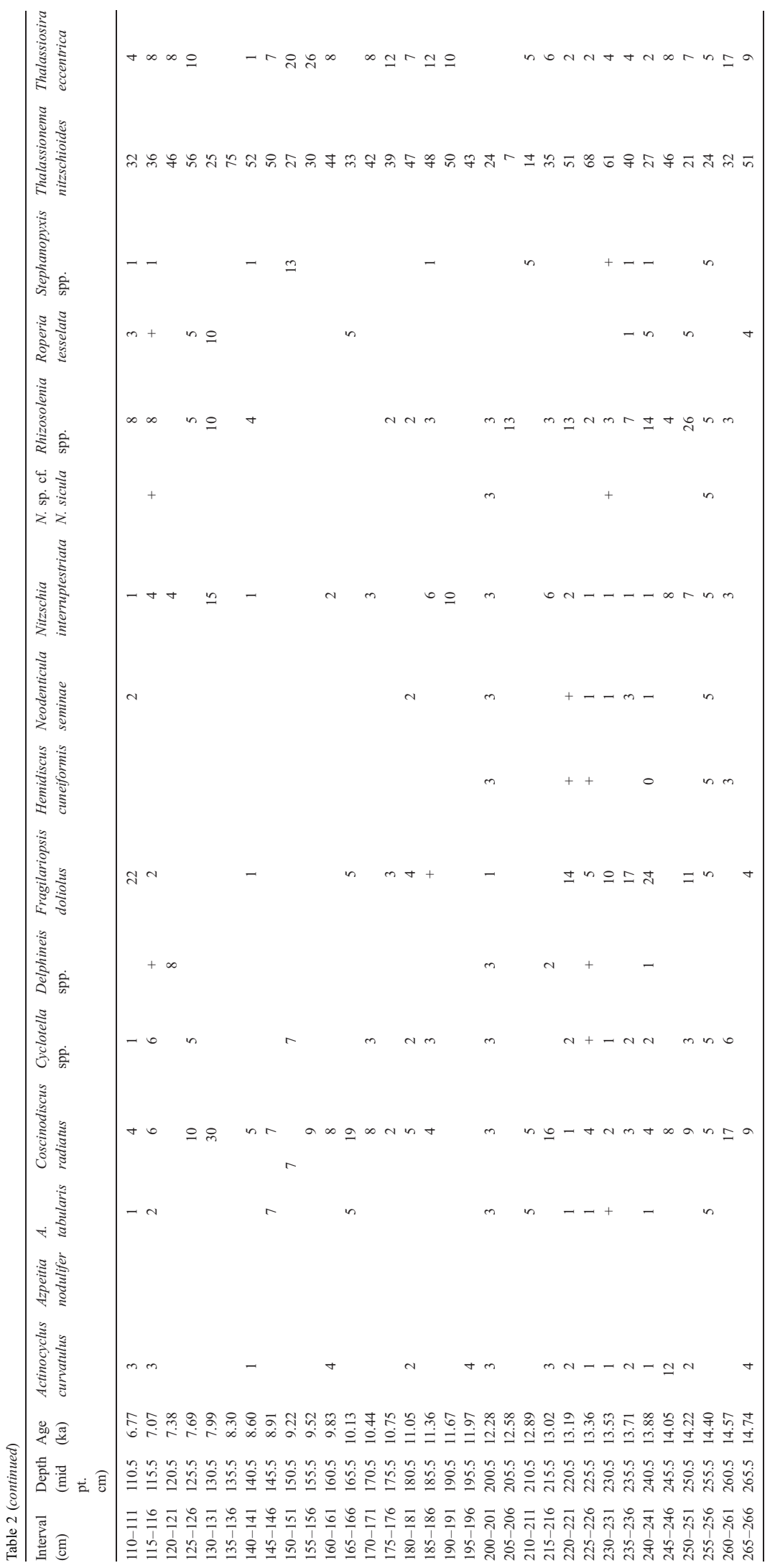




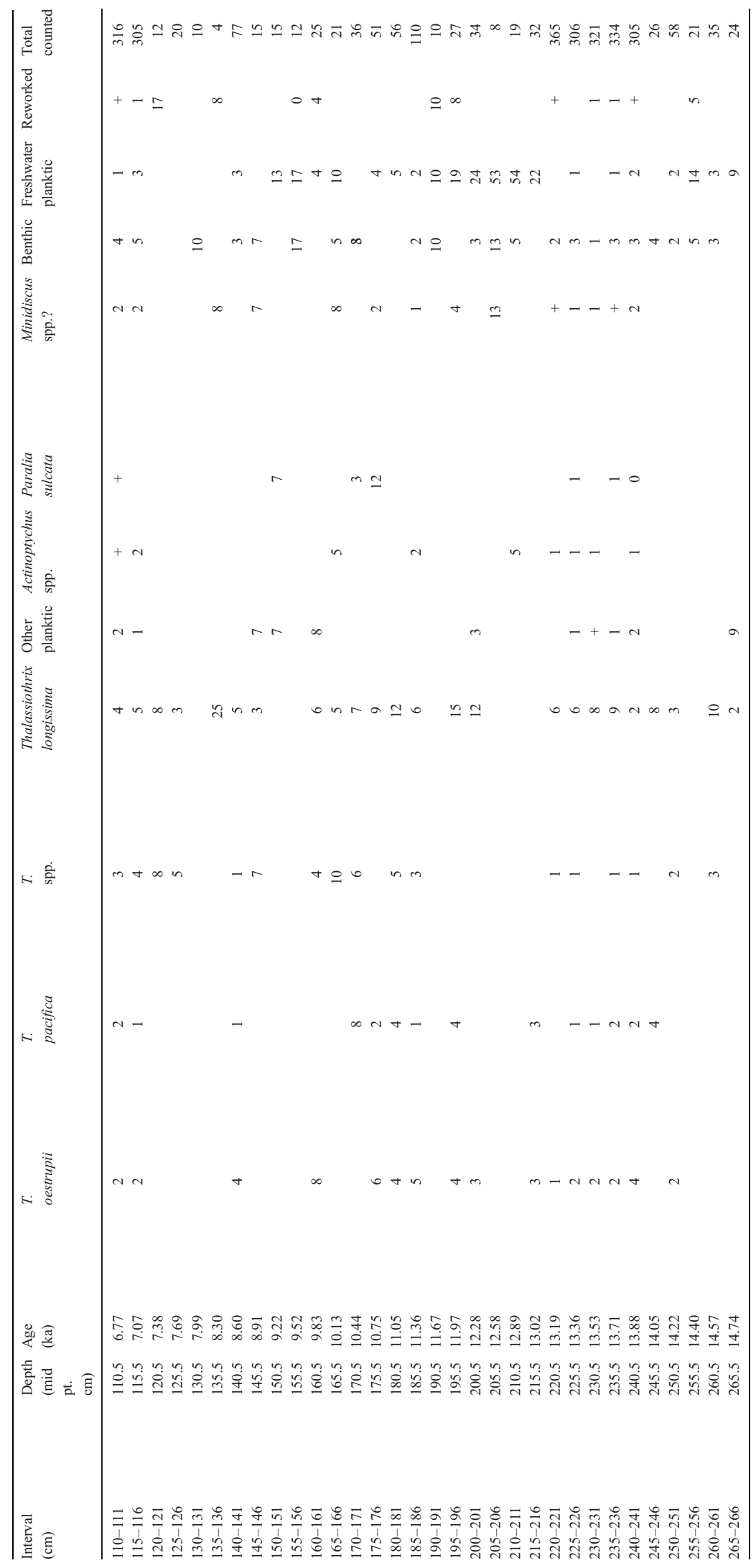



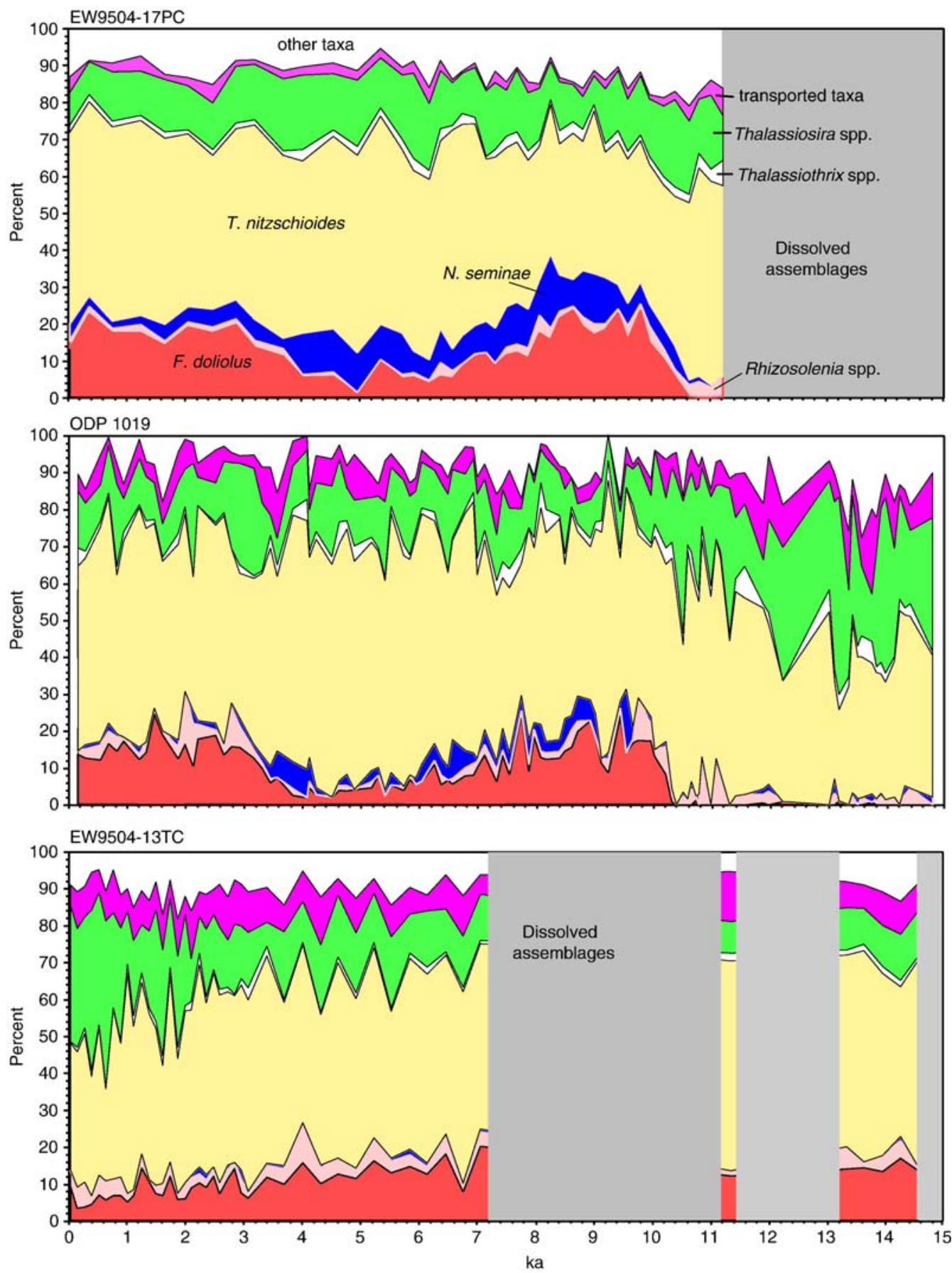

Fig. 3. Relative percentage of key diatom groups in cores EW9504-17PC, ODP 1019, and EW9504-13TC in the Chaetoceros-free diatom assemblage during the past $15,000 \mathrm{yr}$.

The diatom records of all three cores are dominated by Thalassionema nitzschioides. This diatom is most common and most variable at ODP 1019, ranging between 35 and $70 \%$ of the Chaeto- ceros-free diatom assemblage. Relative abundance cycles of $T$. nitzschioides of $\sim 500$ to 1000 yr-duration are apparent in the ODP 1019 data, with greater relative percentage values $(\sim 55$ to $70 \%)$ marking the middle part 
of the Holocene ( $\sim 7$ to $3.5 \mathrm{ka})$. In northern core EW9504-17PC, T. nitzschioides varies between $\sim 35$ and $55 \%$ with no apparent increase during the middle part of the Holocene. In southern core EW9504-13TC, the percentage of $T$. nitzschioides varies between $\sim 30$ and $55 \%$ with higher amplitude cycles after $\sim 2 \mathrm{ka}$. The related group, Thalassiothrix spp., has very minor contributions $(<5 \%)$ in all three records (Fig. 3).

According to Sancetta (1992), T. nitzschioides is a temperate to subtropical taxon that represents springseason production within a broad region extending seaward from the coastal zone. Because T. nitzschioides was most abundant off the coast of Oregon in the Midway Mulitracers sediment trap during the early spring (March-April), Sancetta (1992) suggested that it may be indicative of the oceanic upwelling that occurs at that time.

Lopes et al. (2006) grouped T. nitzschioides with Fragilariopsis doliolus (previously known as Pseudoeunotia doliolus) as a subtropical factor in their study of diatom assemblages in fifty-four core tops from the offshore region of northernmost California, Oregon, and Washington. Unlike Sancetta (1992) and Barron et al. (2003), Lopes et al. (2006) included Chaetoceros spores in their diatom count, so their tabulated assemblage factors reflect the dominance of Chaetoceros spores in nearshore assemblages. Lopes et al. (2006) argued that the high relative abundance of $T$. nitzschioides in areas offshore of northernmost California and southern Oregon may indicate that it is better able to survive in areas of low productivity than the other diatoms species.

Both the EW9504-17PC and ODP 1019 records display a bimodal relative abundance records of $\%$ F. doliolus. Early Holocene $(\sim 10$ to $8 \mathrm{ka})$ and late Holocene $(\sim 3$ to $0 \mathrm{ka})$ intervals of increased values $(>15 \%)$ are separated by a middle Holocene interval $(\sim 6.5$ to $4 \mathrm{ka})$ of greatly reduced $(<5 \%)$ values. The EW9504-13TC record of $\% F$. doliolus does not show such a middle Holocene decrease. Rather, values of \%F. doliolus in EW9504-13TC display a decreasing trend from $\sim 20 \%$ of the Chaetoceros-free assemblage at $\sim 7 \mathrm{ka}$ to $\sim 5 \%$ after $\sim 1 \mathrm{ka}$.

Fragilariopsis doliolus is a diatom associated with the warm-waters of the Central Gyre which enter coastal waters off northern California and southern Oregon in late August to October, when the California Current relaxes (Sancetta, 1992). In the Multitracer sediment trap series off southern Oregon, F. doliolus is most common at the gyre site (17\%) and decreases shoreward (7\% at the midway and $3 \%$ at the nearshore sites) (Sancetta, 1992). F. doliolus appears to represent warm, highly stratified waters with low nutrient availability.

Rhizosolenia spp., which are mostly $R$. hebetata semispina and $R$. styliformis, typically make up $<5 \%$ of the Chaetoceros-free assemblages of the three cores. Southern core EW9504-13TC has the highest relative numbers of Rhizosolenia spp., although the early and late Holocene intervals of ODP 1019 containing increased $\% F$. doliolus values also tend to show increases in \%Rhizosolenia spp.

Neodenticula seminae is associated with cold subarctic waters of the North Pacific. Its existence within the California Current region is thought to represent intrusions of subarctic waters of the North Pacific (Barron et al., 2003; Lopes et al., 2006). Factor 4 of Lopes et al. (2006), which accounts for $9.4 \%$ of their total data, has $N$. seminae as its main species. This factor is located on the northern part of Lopes et al.'s (2006) study area, in both open-ocean and coastal regions, but it does not show any significant correlation to key oceanic properties. Lopes et al. (2006) argue that its presence in diatom assemblage off Oregon and northern California is due to intrusion of subarctic water into the California Current system.

Neodenticula seminae is most common in the northern core EW9504-17PC, where prior to $\sim 4 \mathrm{ka}$, it makes up between 6 and 12\% of the Chaetoceros-free diatom assemblage (Fig. 3). This compares with progressively reduced values of this cold water diatom in records to the south (Fig. 3). At both EW9504$17 \mathrm{PC}$ and ODP $1019, \% N$. seminae declines significantly after $\sim 3.5 \mathrm{ka}$.

Diatoms tabulated as Thalassiosira spp. are dominated by $T$. pacifica with important contributions by $T$. oestrupii, T. eccentrica, and T. lineata. In general, the Thalassiosira spp. group makes up between 10 and $20 \%$ of the Chaetoceros-free assemblages in the records of the three cores. The EW9504-13TC record displays increased $\%$ Thalassiosira spp. to $\sim 30 \%$ after $\sim 2$ ka that is mostly made up by $T$. pacifica, a diatom which Sancetta (1992) considers to be typical of coastal diatom blooms.

Transported diatoms include tychopelagic forms associated with the shelf (Actinoptychus spp., Paralia sulcata, Stephanopyxis spp.), benthic diatoms, freshwater diatoms transported by rivers, and reworked fossil diatoms. The presence of these diatoms in the assemblages at the relatively deep $(>900 \mathrm{~m}$ water depth) core sites is due to downslope transport. Transported diatoms make up less than $10 \%$ of the Chaetoceros-free assemblages in all three cores, with 
northern core EW95014-17PC, the most distant core from shore, displaying the least contribution (typically $2 \%$ or less). There are no clear trends in the percentage transported diatom records other than a small increase in their contribution to the ODP 1019 record prior to $\sim 11 \mathrm{ka}$.

\subsection{Silicoflagellate results}

The relative abundance of silicoflagellate taxa during the past 15,000 yr in cores EW9504-17PC, ODP 1019, and EW9504-13TC is shown in Tables 3-5.

Fig. 4 compares the percentage relative abundance records of the main silicoflagellate groups in these three cores. Dissolved assemblages in EW9504-17PC below $\sim 13 \mathrm{ka}$, in ODP 1019 below $\sim 11 \mathrm{ka}$, and in EW9504$13 \mathrm{TC}$ below $3 \mathrm{ka}$ and above $1.2 \mathrm{ka}$ and the record of EW9504-13TC were not tabulated.

Distephanus speculum s.l., an indicator of cooler, nutrient-rich waters that occur in regions of coastal upwelling (Poelchau, 1976; Takahashi et al., 1989), dominates the records of EW9504-17PC and ODP 1019 , especially after $\sim 10 \mathrm{ka}$. In both records, D. speculum s.l. is most common during the middle part of the Holocene (between $\sim 8$ and 6 to $5 \mathrm{ka}$ ) and again, during the latest Holocene after $\sim 1.5 \mathrm{ka}$. The brief EW9504-13TC record shows moderately common D. speculum s.1. (30-50\%) between $\sim 3$ and 1.6 ka with an increase (to $\sim 60 \%$ ) after $\sim 1.5 \mathrm{ka}$.

Dictyocha aculeata s.l. is a silicoflagellate that ranges from the tropics to the Gulf of Alaska in the eastern North Pacific (Poelchau, 1976). Although it may be tempting to think of $D$. aculeata s.l. as a warm water taxon (Bukry and Foster, 1973; Bukry, 1980), Takahashi et al. (1989) have shown that D. aculeata (his D. mandrai) has its flux maxima during the late fall/early winter in sediment trap Station PAPA $\left(50^{\circ} \mathrm{N}, 145^{\circ} \mathrm{W}\right.$, water depth $4200 \mathrm{~m}$ ) in the eastern subarctic North Pacific. Takahashi et al. (1989) speculated that D. aculeata (D. mandrai) requires high nutrient concentrations but lower light conditions which are typical of deep thermocline conditions occurring during the winter. Thus, increased relative abundance of $D$. aculeata likely reflects a deeper thermocline, in contrast to Distephanus speculum which appears to be a proxy for shallow thermocline conditions associated with coastal upwelling.

The record of $\% D$. aculeata displays a bimodal relative abundance pattern in the EW9504-17PC and ODP 1019 that is opposite to that of D. speculum s.l. $\left(r^{2}=-0.762\right.$ for EW9504-17PC and $r^{2}=-0.631$ for ODP 1019; Fig. 4). Thus, D. aculeata s.l. is relatively common prior to $\sim 9 \mathrm{ka}$ and between $\sim 5$ and $2 \mathrm{ka}$, but it is relatively sparse during the middle and latest part of the Holocene (compare also the record of EW950413TC).

Dictyocha stapedia is a tropical to temperate taxon that is associated with low nutrient (oligotrophic) conditions (Poelchau, 1976; Takahashi et al., 1989; Barron et al., 2005). Onodera and Takahashi (2005) consider D. stapedia (their D. messanenesis) to be a subtropical species, noting that its relative abundance closely follows increases in SST occurring during the summer at sediment trap Station $40 \mathrm{~N}$ $\left(40^{\circ} 00^{\prime} \mathrm{N}, 165^{\circ} 00^{\prime} \mathrm{E}\right.$, water depth $\left.5476 \mathrm{~m}\right)$ in the northwestern Pacific. Therefore, off northern California and southern Oregon, D. stapedia is likely associated with the relatively warm, low nutrient waters of the Central Gyre, which move shoreward during late August to October (Bolin and Abbott, 1962) after the southward flow of the California Current diminishes.

Dictyocha stapedia displays similar relative abundance records in EW9504-17PC, ODP 1019, and EW9504-13TC, typically ranging between 10 and 20\% of the silicoflagellate assemblage (Fig. 4). The EW9504-17PC record includes two stepwise increases, one at $\sim 11.6 \mathrm{ka}$, where $\% D$. stapedia increases from $<2 \%$ to $\sim 10-15 \%$, and a second at $\sim 6 \mathrm{ka}$, where $\% D$. stapedia increases to $>20 \%$. The ODP 1019 record of $\%$ D. stapedia resembles that of EW9504-17PC but with slightly lower and more variable values. The brief record of D. stapedia in EW9504-13TC reveals relative abundances that are similar to those of EW9504-17PC.

Distephanus octangulatus is a subarctic silicoflagellate that is most common in cooler waters of the North Pacific including the Bering Sea and Alaskan Gyre (Ling, 1973; Poelchau, 1976; Takahashi, 1987). In general, D. octangulatus makes up less than $5 \%$ of the silicoflagellate assemblages of EW9504-17PC, ODP 1019, and EW9504-13TC with relative abundances increasing slightly to the north (Fig. 4). Increased $\% D$. octangulatus in EW9504-17PC prior to $\sim 11$ ka possibly implies greater southward penetration of subarctic waters.

\section{Discussion}

\subsection{SST proxy comparison}

Barron et al. (2003) showed that the alkenone SST record and the record of $\% F$. doliolus at ODP 1019 were very similar, with a cool (low) middle Holocene $(\sim 8$ to 


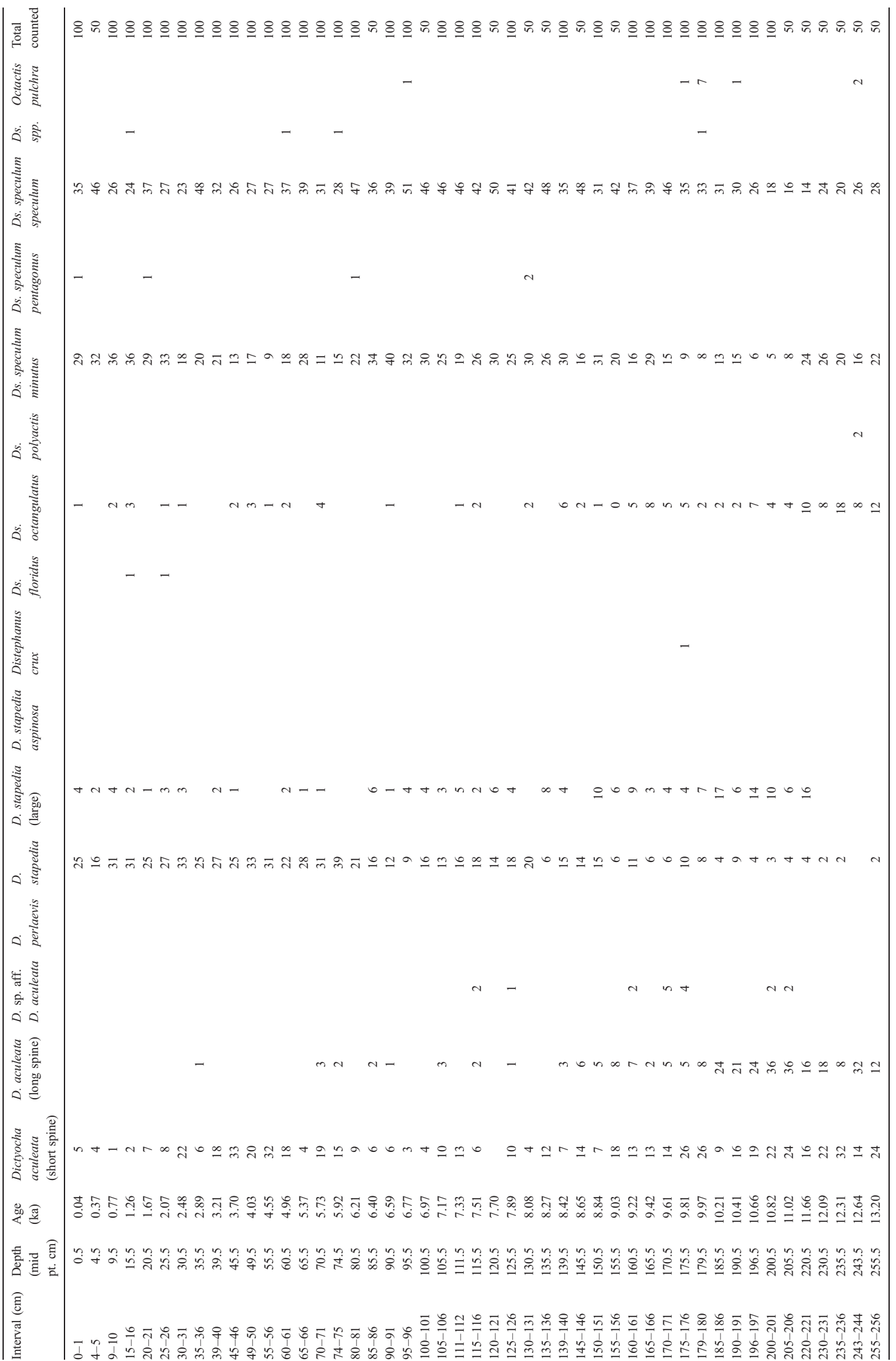




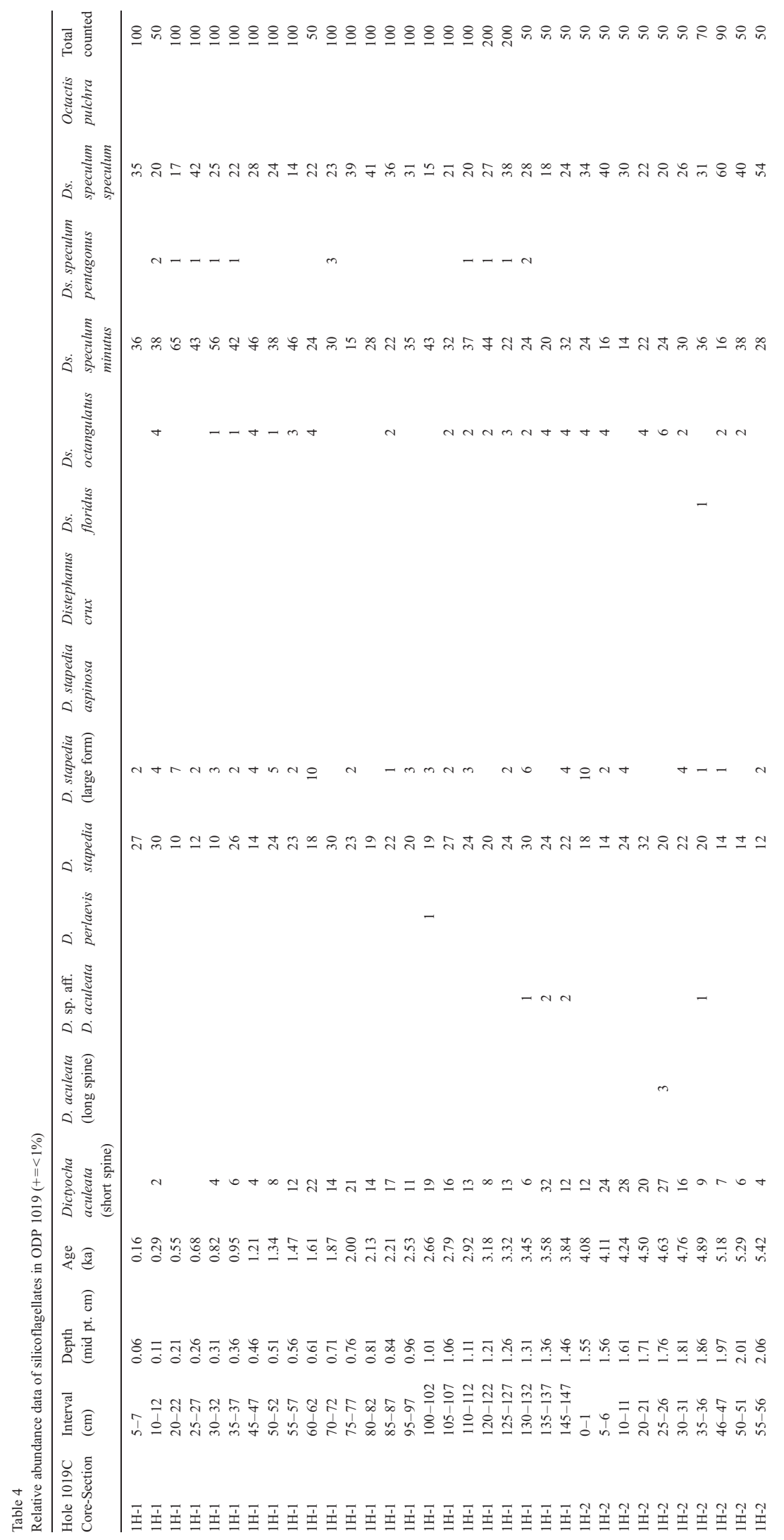




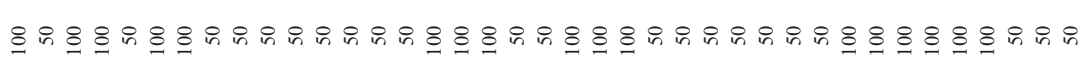

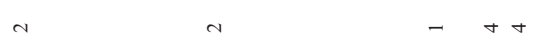

๓

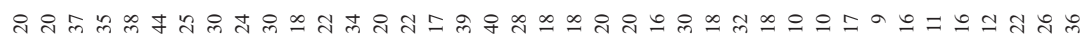

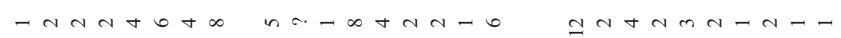

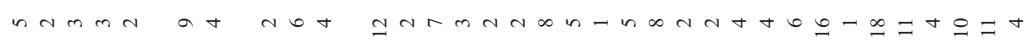

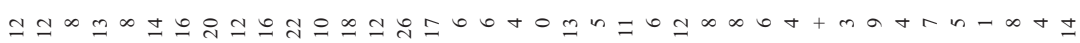

아

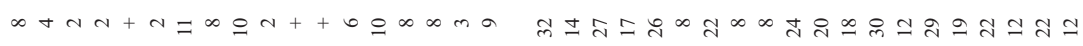

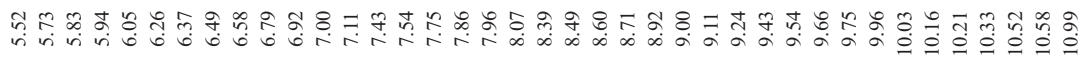

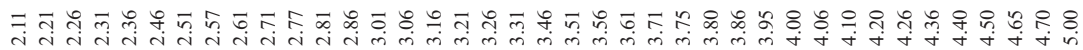

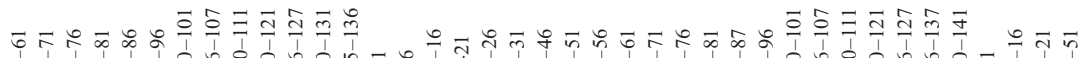

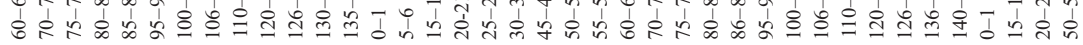

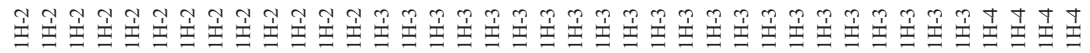




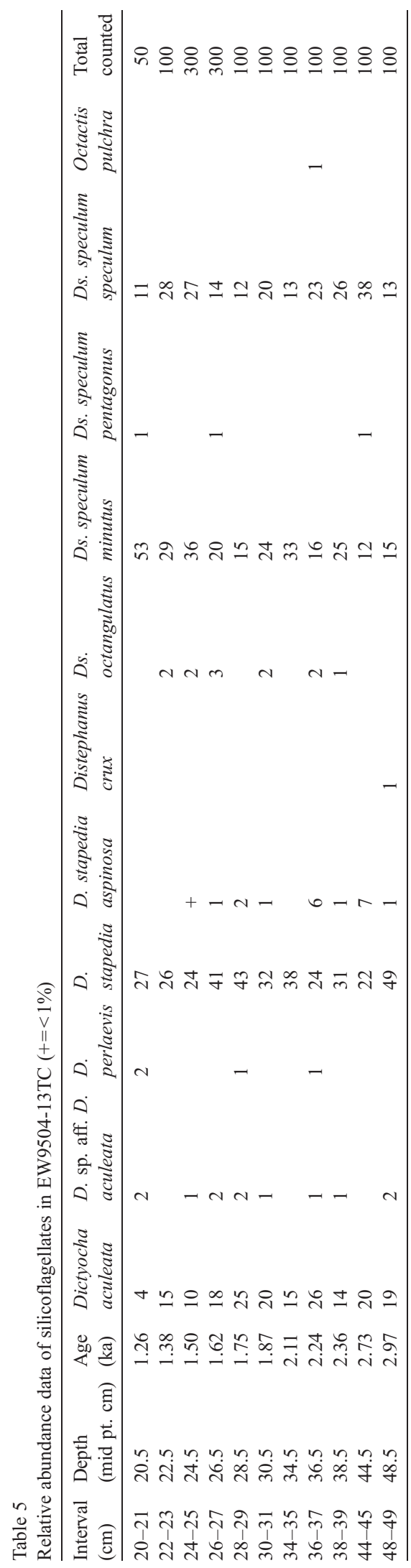

$4 \mathrm{ka}$ ) values separating warmer (lower) values in the Holocene prior to $\sim 8 \mathrm{ka}$ and after $\sim 3.2 \mathrm{ka}$. Because $F$. doliolus is associated with the warm waters of the Central Gyre, Barron et al. (2003) argued that the $\%$ F. doliolus record at ODP 1019 was a proxy for early fall (September-October) SST, the period when offshore waters move shoreward and SST reaches it maximum. The sudden increase of $\%$ F. doliolus at $\sim 10$ ka during a period of warm alkenone SST is assumed to have been due to increasing opal content in the sediments and improving diatom preservation rather than warming (Barron et al., 2003).

Fig. 5 reveals that $\% F$. doliolus record at EW9504$17 \mathrm{PC}$ is remarkably similar to both $\% F$. doliolus and alkenone SST records of ODP 1019 in that it suggests surface water cooling during the middle part of the Holocene. The \%F. doliolus record at EW9504-13TC, however, does not show middle Holocene cooling (Fig. 3), possibly because it lay seaward from the region of active coastal upwelling during the middle prat of the Holocene.

Between $\sim 3.4$ and $3.2 \mathrm{ka}$, a three-fold increase in the relative percent of $F$. doliolus at ODP 1019 and EW9504-17PC coincides with a permanent warming of alkenone SST's by $\sim 1{ }^{\circ} \mathrm{C}$. As mentioned earlier, Kim et al. (2004) found that this 4 to $3 \mathrm{ka}$ abrupt increase in SST is a common feature of northeastern Pacific alkenone records. Although these authors did not suggest a cause for this SST increase, Barron et al. (2003) cited Clement et al. (2000) and Sandweiss et al. (2001) in arguing that this $\sim 3.4$ to $3.2 \mathrm{ka}$ shift to warmer SST at ODP 1019 was an expression of increasing ENSO variability. Barron et al. (2003) suggested that the $\sim 3.4$ to $3.2 \mathrm{ka}$ warming of alkenone and diatom proxy SST at ODP 1019 reflected a more frequent occurrence of El Niño-like conditions in offshore waters during the early fall. This is supported by the atmospheric modeling studies of Diffenbaugh et al. (2003) which argue that during the middle Holocene, coastal upwelling off California extended into the early part of the fall.

In addition to Kim et al. (2004), other studies report major climate transitions between $\sim 4$ and 3 ka that appear to be an expression of enhanced ENSO cycles along the Pacific margin of North America between $\sim 35^{\circ}$ and $50^{\circ} \mathrm{N}$ latitude. Patterson et al. (2004) document a major climate shift at $3.4 \mathrm{ka}$ to a higher rainfall regime in southern coastal British Columbia in their detailed study of varved sediments and fish stocks in Effingham Inlet on Vancouver Island. Benson et al. (2002) report a shift of $\delta^{18} \mathrm{O}$ of sediments to more positive values in Pyramid Lake, Nevada, between 3.43 


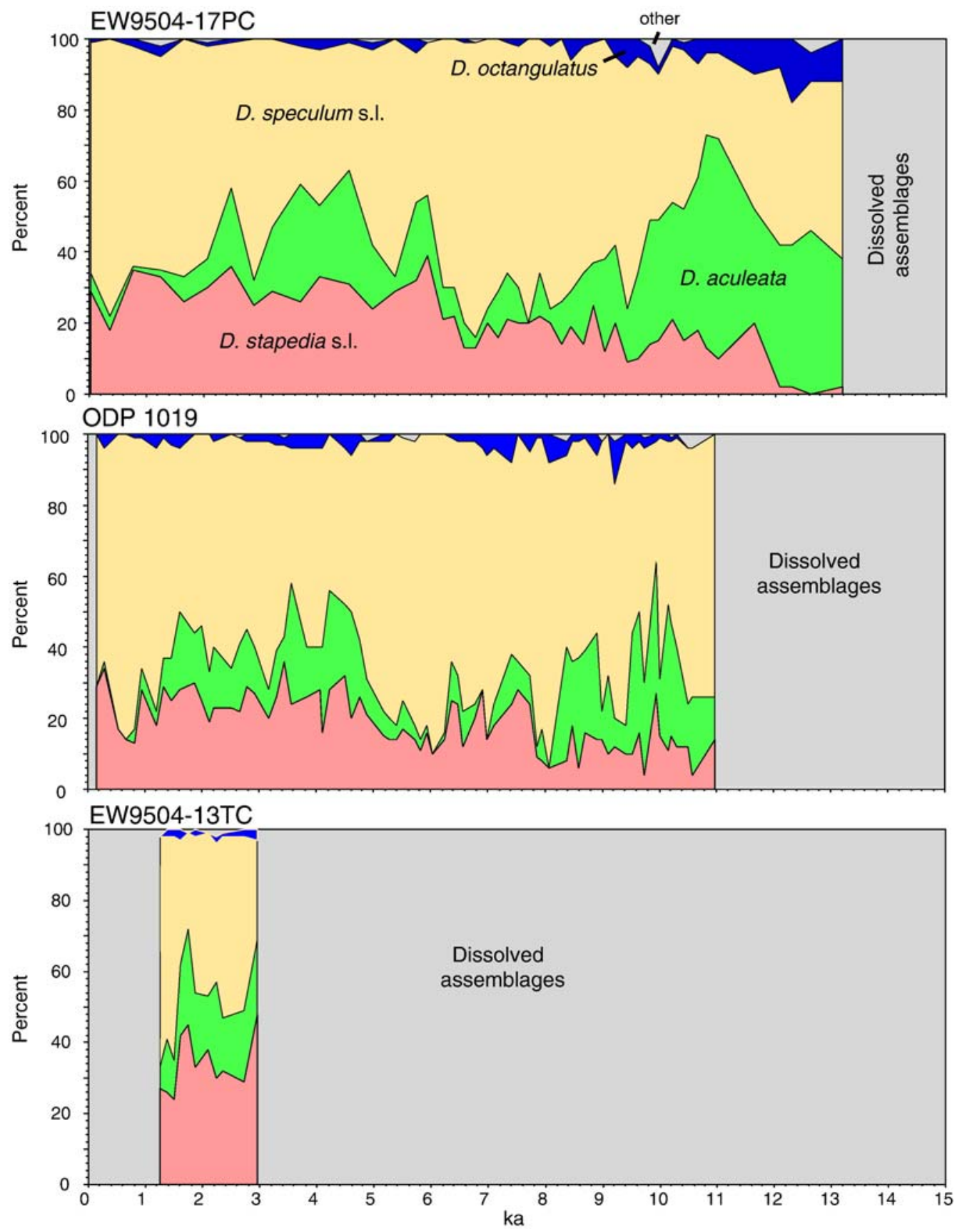

Fig. 4. Relative percentage of key silicoflagellate groups in cores EW9504-17PC, ODP 1019, and EW9504-13TC during the past 15,000 yr.

and $3.1 \mathrm{ka}$, which represents a shift toward cooler and wetter climate after a long period of mid-Holocene drought. Increased expression of ENSO cycles between $\sim 4$ and $3 \mathrm{ka}$ is also documented by Haug et al. (2001) in the Cariaco Basin of the Caribbean.

Coral studies from the western Pacific warm pool suggest weaker ENSO variability during the middle part of the Holocene ( $\sim 6 \mathrm{ka}$ )(Gagan et al., 1998; Tudhope et al., 2001). In the eastern equatorial Pacific, Koutavas et al. (2002) argue for cooler, La Niña-like conditions between $\sim 8$ and $5 \mathrm{ka}$ based on SST records derived from magnesium/calcium ratios in planktic foraminifers from a core taken near the Galapagos Island. These studies support Barron et al.'s (2003) arguments that 

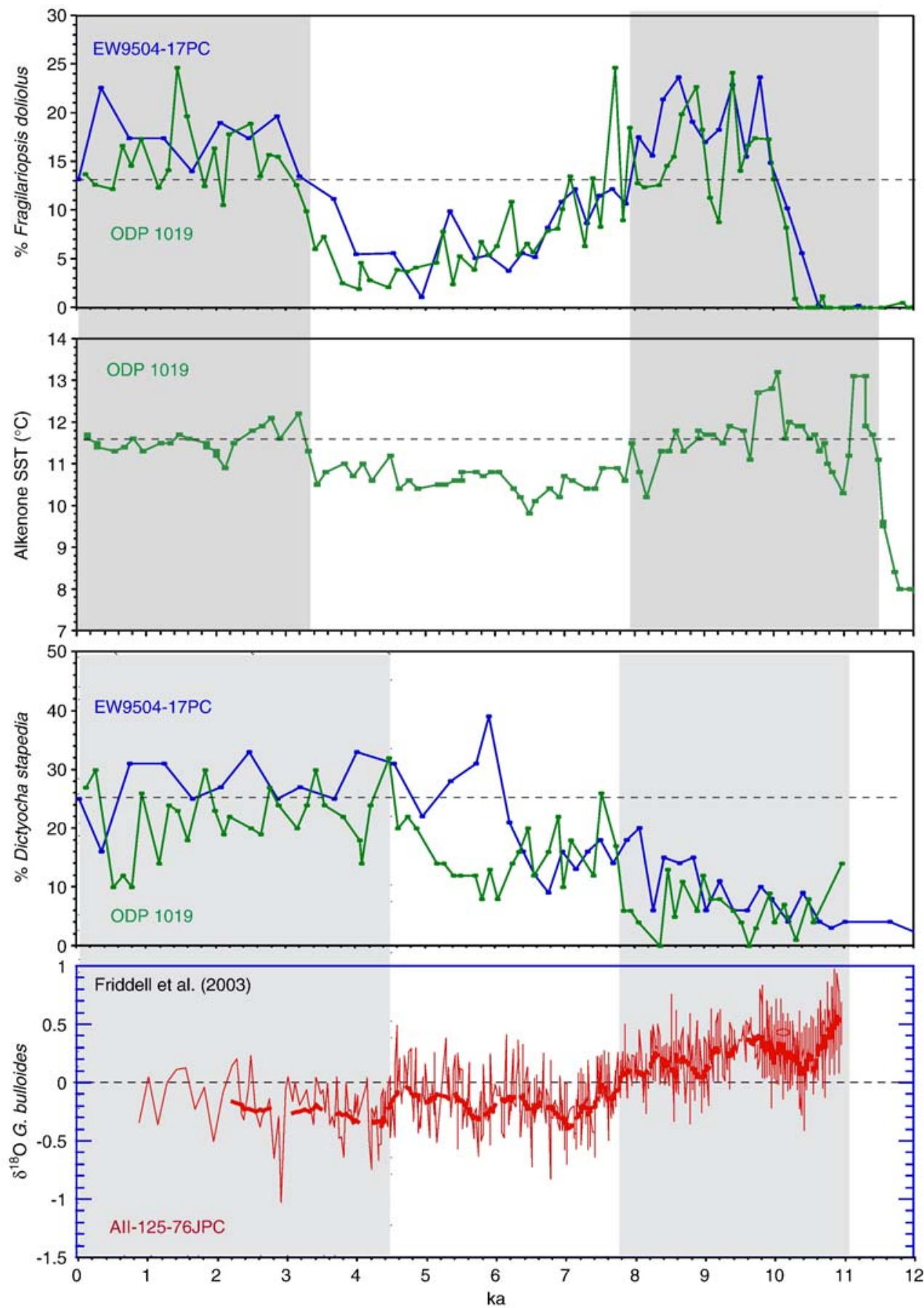

Fig. 5. Comparison of the \%Fragilariopsis doliolus records of EW9504-17PC and ODP 1019 (proxy for the central Gyre) with the ODP 1019 alkenone SST record of Barron (2003), the \%Dictyocha stapedia records of EW9504-17PC and ODP 1019 (proxy for warm water), and the record of $\delta^{18}$ O Globigerina bulloides of Friddell et al. (2003) in the Santa Barbara Basin. (thick line $=20$ pt. smoothed data). Shaded areas represent warmer intervals.

cooler SST during middle part of the Holocene off northern California was reflective of La Niña-like conditions in the equatorial Pacific.
Fig. 5 also includes the \%Dictyocha stapedia records at EW9504-17PC and ODP 1019. Dictyocha stapedia is a proxy of low nutrient, subtropical waters in the North 
Pacific (Poelchau, 1976; Onodera and Takahashi, 2005), and it is assumed that the $\% D$. stapedia records of EW9504-17PC and ODP 1019 record the influence of warmer, low nutrient waters of the Central Gyre. Changes in \%D. stapedia in EW9504-17PC and ODP 1019 , do not parallel the SST changes suggested by the ODP 1019 alkenone data and the $\% F$. doliolus data. Rather, $\%$ D. stapedia increases in a stepwise manner at both EW9504-17PC and ODP 1019 during the midHolocene interval of supposed cooler SST (Fig. 5). In EW9504-17PC, \%D. stapedia roughly doubles between $\sim 6.4$ and $6.0 \mathrm{ka}$, while at ODP $1019 \%$ D. stapedia shows a more gradual increase with two steps occurring at $\sim 7.6$ and between $\sim 5.0$ and $4.5 \mathrm{ka}$.

The $\sim 7.6$ and $\sim 5.0-4.5 \mathrm{ka} \% D$. stapedia steps at ODP 1019 coincide with stepwise decreases in $\delta^{18} \mathrm{O}$ of the foraminifer Globigerina bulloides in the SBB (Friddell et al. (2003) (Fig. 5). Although Friddell et al. (2003) interpret their $\sim 7.6$ and $\sim 5.0-4.5 \mathrm{ka}$ steps in decreasing $\delta^{18} \mathrm{O}$ to reflect surface water warming in the SBB, Field (2004) and Pak et al. (2004) point out that G. bulloides lives near the chlorophyll maximum which is at subsurface depths between 10 and $40 \mathrm{~m}$ in the SBB. As higher fluxes of $G$. bulloides can occur during all seasons of the year in SBB, Field (2004) and Pak et al. (2004) argue that there should be no seasonal bias to the $\delta^{18} \mathrm{O}$ record of $G$. bulloides. In explaining differences between historic $\delta^{18} \mathrm{O} G$. bulloides paleotemperature estimates and recent climatic data, Field (2004) cautions that surface water warming (cooling) can result in a downward (upward) shift in the depth of the chlorophyll maximum, causing $G$. bulloides to migrate to deeper (shallower) depths in the water column where it may record a heavier (lighter) $\delta^{18} \mathrm{O}$ signal. Thus, it is unclear whether Friddell et al.'s (2003) $~ 7.6$ and $\sim 5.0-4.5 \mathrm{ka}$ steps in decreasing $\delta^{18} \mathrm{O}$ of $G$. bulloides reflect surface water warming or cooling in the SBB. It should also be pointed out that the $\sim 7.6 \mathrm{ka}$ decrease in the $\delta^{18} \mathrm{O}$ of $G$. bulloides occurred during a period when global sea level was still rising, suggesting that it might reflect decreasing ice volume rather than surface water warming.

If the $\sim 5.0-4.5 \mathrm{ka}$ decrease in the $\delta^{18} \mathrm{O}$ of $G$. bulloides reflects surface water warming in the SBB, it was likely due to an intensification of the northerly flow of the Southern California Countercurrent (SCC) (Fig. 1). The SCC develops in the SBB during the summer, as a result of evolving differences in the strength of offshore $v s$. nearshore upwelling cells south of Pt. Conception (Di Lorenzo, 2003). The mid Holocene stepwise increases in $\% D$. stapedia at ODP 1019 and EW9504-17PC likely reflect a seasonal narrowing of the California Current that ultimately could have affected the strength of the SCC and caused surface water warming in the SBB. Unfortunately, Holocene alkenone studies in the SBB (Herbert et al., 1995) are not detailed enough to resolve this hypothetic teleconnection.

\subsection{Upwelling and surface water stratification}

Figs. 6 and 7 compare the records of Dictyocha aculeata and Distephanus speculum in EW9504-17PC and ODP 1019 with Friddell et al.'s (2003) record of surface water stratification in the SBB. As noted earlier, the strong negative correlation of $\% D$. aculeata and $\%$ D. speculum in Holocene samples studied from EW9504-17PC and ODP 1019 are evidence that they represent contrasting oceanographic conditions. Whereas $D$. aculeata prefers lower light conditions typical of a deeper thermocline, $D$. speculum is more common in high nutrient conditions where the thermocline is relatively shallow (Takahashi et al., 1989; Onodera and Takahashi, 2005).

In coastal regions affected by the California Current, strong northerly winds during the spring and summer lead to coastal upwelling, a shoaling of the thermocline and high productivity conditions. During the winter, the North Pacific High moves to the south, the winds are mainly southerly, feeding both the north flowing Davidson Current and the California Undercurrent. These currents transport a biota typical of southerly waters, such as D. aculeata, to the north. Based on these contrasting relationships and the sediment trap studies of Takahashi et al. (1989), it is proposed that higher relative numbers of $D$. speculum in the records of EW9504-17PC and ODP 1019 are indicative of periods that were dominated by spring-summer conditions of coastal upwelling and a shallow thermocline. Increased relative numbers of $D$. aculeata, on the other hand, are assumed to be indicative of intervals dominated by winter-like conditions, when the California Current was relatively weak, and a north-flowing current with a relatively deep thermocline was more typical.

Two intervals of increased $\% D$. aculeata in the records of EW9504-17PC and ODP 1019 appear to correlate with intervals of increased water mass stratification identified by Friddell et al. (2003) in the SBB (Fig. 6). The earlier interval, prior to $\sim 9 \mathrm{ka}$, coincides with the presence of calcium carbonate in ODP 1019 and other offshore cores from the region (Lyle et al., 2000). This pre 9 ka-interval likely represents a time prior to the initiation of strong southward flow of the cool-water California Current, 

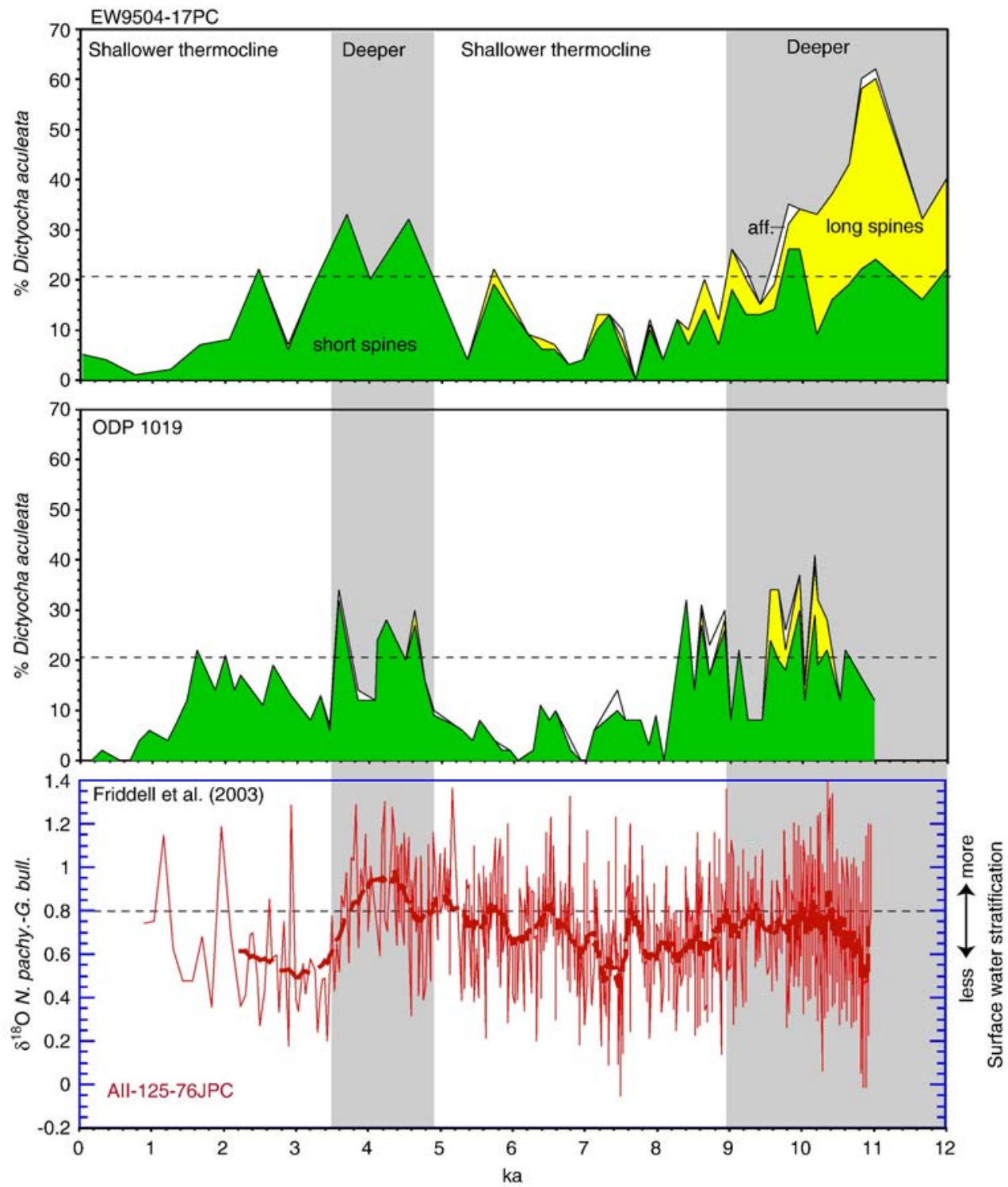

Fig. 6. Comparison of the \%Dictyocha aculeata records of EW9504-17PC and ODP 1019 (proxy for a deep thermocline) with Friddell et al.'s (2003) $\delta^{18} \mathrm{O}$ N. pachyderma - G. bulloides record of thermal stratification of surface waters in the Santa Barbara Basin (thick line $=20$ pt. smoothed data). Shaded areas represent a deeper thermocline.

when subtropical waters penetrated northward along the coast to southern Oregon (Mix et al., 1999; Barron et al., 2003).

The relative abundance of three different forms of D. aculeata is shown on Fig. 6. Long spine forms of D. aculeata, which are typical of the tropical Pacific (Bukry and Foster, 1973; McCartney et al., 1995), are most common prior to $\sim 10 \mathrm{ka}$. Short spine forms of D. aculeata, which are associated with temperate North Pacific waters, range throughout the Holocene in both EW9505-17PC and ODP 1019. Aberrant forms, tabulated as $D$. sp. aff. D. aculeata, are exceedingly sparse.

The latter interval of increased $\% D$. aculeata in EW9504-17PC and ODP 1019 between 4.8 and $3.6 \mathrm{ka}$ coincides with greater surface water stratification in the SBB. Friddell et al. (2003) suggest that this interval coincides with an increased occurrence of El Niño events. In the western North Pacific region affected by the north-flowing Kuroshio Current, Ujiié et al. (2003) identify an interval between $\sim 4.5$ and 3.0 ka that is typified by reduced relative number of the planktic 

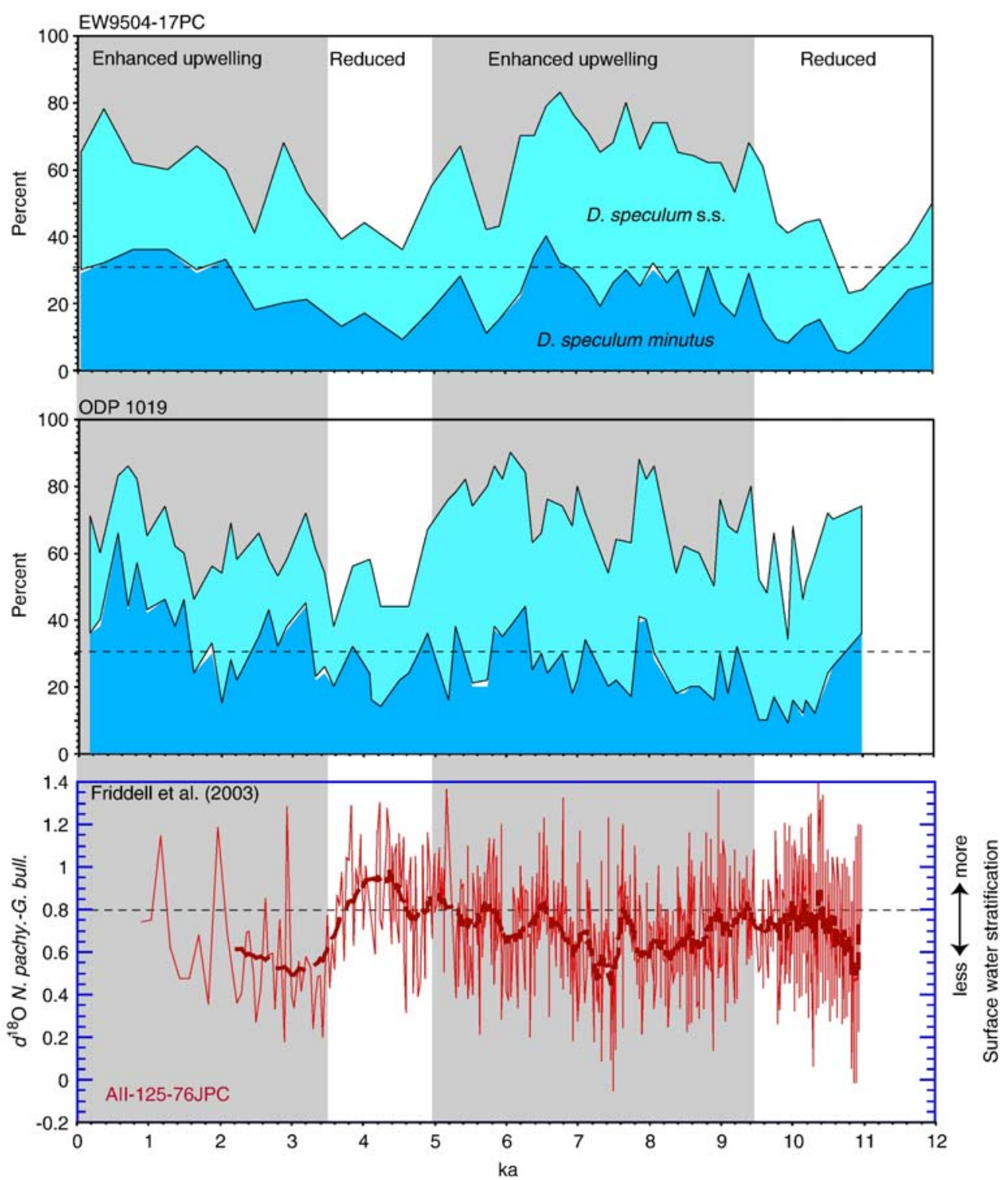

Fig. 7. Comparison of the \%Distephanus speculum records of EW9504-17PC and ODP 1019 (proxy for coastal upwelling and/or a shallow thermocline) with Friddell et al.'s (2003) $\delta^{18} \mathrm{O}$ N. pachyderma-G. bulloides record of thermal stratification of surface waters in the Santa Barbara Basin (thick line $=20$ pt. smoothed data). Shaded areas represent enhanced upwelling an/or a shallower thermocline.

foraminifer Pulleniatina obliquiloculata, the so-called Pulleniatina Minimum Event (PME). Ujiié et al. (2003) argue that the PME represents a period of reduced northward flow of the Kuroshio Current caused by enhanced El Niño-like conditions in the tropical Pacific. In support of this hypothesis, Corrège et al. (2000) document strong ENSO variability in a coral from Vanuatu which is dated at $4.15 \mathrm{ka}$. It is possible that the $\sim 4.8$ to $3.6 \mathrm{ka}$ interval of increased \% D. aculeata in the northern California Current coincides with reduced gryal circulation in the North Pacific, i.e., slackening of both the Kuroshio and California Currents.

Fig. 7 compares the \%Distephanus speculum records of EW9504-17PC and ODP 1019 with Friddell et al.'s (2003) record of surface water stratification in the SBB. In these plots, D. speculum s.s. is separated from D. speculum minutus, as emended by Bukry (1981), a form that has an apical ring that in plan view is contiguous or overlaps the basal ring. 
Distephanus speculum minutus has a long geological record beginning in the Miocene (Bukry and Foster, 1973) and is most abundant in high latitude areas. In the North Pacific and Bering Sea cores of DSDP Leg 19, Bukry (1973) noted, "High-latitude populations (of Distephanus speculum) have a high proportion of a form that has short spines and a large apical ring. This is presumably an intraspecific phenotypic response to colder surface water at high latitude". Studies of Miocene and younger sediments show that $D$. speculum minutus increases its relative numbers poleward compared to populations of $D$. speculum s.s., (Bukry, 1976, 1981, 1986, 1987). Analyses of Holocene silicoflagellate populations in the eastern North Pacific (D. Bukry, unpublished data) confirm that $D$. speculum minutus is restricted to cooler waters north of Pt. Conception $\left(34^{\circ} \mathrm{N}\right)$ with its relative abundance increasing northward to piston core EW0408-07JC from offshore waters of Cordova Bay, Alaska $\left(\sim 55^{\circ} \mathrm{N}\right)$. Thus, increased $\% D$. speculum minutus in ODP 1019 and EW9504-17PC is inferred to reflect cooling of surface waters.

Fig. 7 shows that increased $\% D$. speculum s.s. and $\% D$. speculum minutus occurring between $\sim 9.5$ and $5 \mathrm{ka}$ and after $\sim 3.2 \mathrm{ka}$ coincide with decreased water mass stratification in the SBB. At ODP 1019, which lies closer to the coast, fluctuations in $\% D$. speculum minutus make up most of the change of this silicoflagellate proxy upwelling record. Intervals of $\% D$. speculum minutus $>30 \%$ of the silicoflagellate assemblage dominate the ODP 1019 record after $3.2 \mathrm{ka}$, attesting to increased spring-summer upwelling. This agrees with the conclusions of Barron et al. (2003) who argued that increases of \%Sequoia (coastal redwood) in the ODP 1019 pollen record after 3.4 ka were evidence for increased coastal upwelling. A second increase of $\%$ D. speculum minutus in the ODP 1019 record after $\sim 1.5 \mathrm{ka}$ argues for a further intensification of coastal upwelling.

\section{Conclusions}

Diatom and silicoflagellate records in piston core EW9504-17PC off southern Oregon, ODP 1019 off northernmost California, and piston core EW9504-13TC off central California reveal the evolution of the northern part of the California Current during the past 12,000 yr.

Prior to $\sim 9 \mathrm{ka}$, the California Current was relatively weak. Surface waters off northern California and southern Oregon were relatively warm with a deep thermocline. Alkenone studies at ODP 1019 suggest that SST exceeded modern values during much of the early
Holocene period prior to $\sim 9.7 \mathrm{ka}$. Diatom and silicoflagellate preservation was typically poor prior to $\sim 10 \mathrm{ka}$, presumably reflecting the low nutrient content of surface waters.

Southward flow of the California Current intensified between $\sim 9$ and $8 \mathrm{ka}$, resulting in surface water cooling and increased coastal upwelling off northern California and southern Oregon. This $\sim 9$ to $8 \mathrm{ka}$ Holocene strengthening of the California Current is documented as far south as Point Conception $\left(\sim 34^{\circ} \mathrm{N}\right)$ (Seki et al., 2002), but it is not apparent in the Santa Barbara Basin, which is more affected by subtropical waters flowing northward as part of the Southern California Countercurrent.

Increased relative abundance of Dictyocha aculeata, a silicoflagellate associated with deeper thermocline conditions, between $\sim 4.8$ and 3.6 ka coincides with great water mass stratification in the Santa Barbara Basin, suggesting a slackening in the southward flow of the California Current. Coincidence of this interval with the Pulleniatina Minimum Event in the western North Pacific (Ujiié et al., 2003) suggests a period of reduced gyral circulation in the North Pacific.

Modern seasonal oceanographic cycles off northern California and southern Oregon evolved between 3.5 and $3.2 \mathrm{ka}$, as evidenced by increased spring-early summer coastal upwelling and warming of early fall SST. Widespread occurrence of paleoceanographic and paleoclimatic change documented between $\sim 3.5-3.0 \mathrm{ka}$ along the eastern margins of the North Pacific (Benson et al., 2002; Patterson et al., 2004; Kim et al., 2004) was likely a response to increasing ENSO variability in the tropical Pacific (Clement et al., 2000; Barron et al., 2003).

\section{Acknowledgements}

This manuscript benefited from reviews by Scott W. Starratt and Mary McGann of the USGS and from helpful discussions with Kozo Takahashi and David Field. We thank Bobbi Conrad of the core laboratory of the College of Ocean and Atmospheric Sciences, Oregon State University for providing the samples from EW9504-13TC and 9504-17PC. We are grateful to suggestions offered by Thierry Corrège, the journal editor, and an anonymous reviewer in their formal reviews of our paper.

\section{References}

Barron, J.A., Heusser, L., Herbert, T., Lyle, M., 2003. High resolution climatic evolution of coastal northern California during the past 16,000 years. Paleoceanography 18. doi:10.1029/2002PA000768. 
Barron, J.A., Bukry, D., Bischoff, J.L., 2004. High resolution paleoceanography of the Guaymas Basin, Gulf of California, during the past 15,000 years. Marine Micropaleontology 50, 185-207.

Barron, J.A., Bukry, D., Dean, W.A., 2005. Paleoceanographic history of the Guaymas Basin, Gulf of California, during the past 15,000 years based on diatoms, silicoflagellates, and biogenic sediments. Marine Micropaleontology 56, 81-102.

Benson, L., Kashgarian, M., Rye, R., Lund, S., Paillet, F., Smoot, J., Kester, C., Mensing, S., Meko, D., Lindstrom, S., 2002. Holocene multidecadal and multicentennial droughts affecting Northern California and Nevada. Quaternary Science Reviews 21, 659-682.

Bograd, S.J., Schwing, F.B., Mendelssohn, R., Green-Jessen, P., 2002. On the changing seasonality over the North Pacific. Geophysical Research Letters 29 (9). doi:10.1029/2001GL013790.

Bolin, R.L., Abbott, D.P., 1962. Studies on the marine climate and phytoplankton of the central coast area of California, 1954-60. CalCOFI Report 9, 24-45.

Bukry, D., 1973. Coccolith and silicoflagellate stratigraphy, Deep Sea Drilling Project, Leg 18, eastern North Pacific. Initial Reports of the Deep Sea Drilling Project 18, 817-831.

Bukry, D., 1976. Cenozoic silicoflagellate and coccolith stratigraphy, South Atlantic Ocean, Deep Sea Drilling Project Leg 36. Initial Reports of the Deep Sea Drilling Project 35, 885-917.

Bukry, D., 1980. Silicoflagellate biostratigraphy and paleoecology in the eastern Pacific Ocean, Deep Sea Drilling Project Leg 54. Initial Reports of the Deep Sea Drilling Project 54, 545-573.

Bukry, D., 1981. Silicoflagellate stratigraphy of offshore California and Baja California, Deep Sea Drilling Project Leg 63. Initial Reports of the Deep Sea Drilling Project 63, 539-557.

Bukry, D., 1986. Miocene silicoflagellates from Chatham Rise, Deep Sea Drilling Project Site 594. Initial Reports of the Deep Sea Drilling Project 90, 925-937.

Bukry, D., 1987. North Atlantic Quaternary silicoflagellates, Deep Sea Drilling Project Leg 94. Initial Reports of the Deep Sea Drilling Project 94, 779-783.

Bukry, D., Foster, J.H., 1973. Silicoflagellate and diatom stratigraphy, Leg 16, Deep Sea Drilling Project. Initial Reports of the Deep Sea Drilling Project 16, 815-871.

Clement, A.C., Seager, R., Cane, M.A., 2000. Suppression of El Niño during the mid-Holocene by changes in the Earth's orbit. Paleoceanography $15,731-737$.

Corrège, T., Delcroix, T., Recy, J., Beck, W., Cabioch, G., Le Cornec, F., 2000. Evidence for stronger El Niño-Southern Oscillation (ENSO) events in a mid-Holocene massive coral. Paleoceanography $15,465-470$.

Diffenbaugh, N.S., Sloan, L.C., Snyder, M.A., 2003. Orbital suppression of wind driven upwelling in the California Current at 6 ka. Paleoceanography 18 (2), 1051. doi:10.1029/2002PA000865.

Di Lorenzo, E., 2003. Seasonal dynamics of the surface circulation in the Southern California Current System. Deep-Sea Research II 50, 2371-2388.

Doose, H., Prahl, F.G., Lyle, M.W., 1997. Biomarker temperature estimates for modern and last glacial surface waters of the California Current system between $33^{\circ}$ and $42^{\circ} \mathrm{N}$. Paleoceanography 12 (4), $615-622$.

Field, D.B., 2004. Variability in vertical distributions of planktonic foraminifera in the California Current: relationships in vertical ocean structure. Paleoceanography 19, A2014. doi:10.1029/2003PA000970.

Fleming, E.L., Lim, G.-H., Wallace, J.M., 1987. Differences between the spring and autumn circulation of the Northern Hemisphere. Journal of Atmospheric Science 44, 1266-1286.
Friddell, J.E, Thunell, R.C., Guilderson, T.P., Kashgarian, M., 2003. Increased northeast Pacific climatic variability during the warm middle Holocene. Geophysical Research Letters 30 (11), 1-4.

Gagan, M.K., Ayliffe, L.K., Hopley, D., Cali, J.A., Mortimer, G.E., Chappell, J., McCulloch, M.T., Head, M.J., 1998. Temperature and surface-ocean water balance of the mid-Holocene tropical western Pacific. Science 279, 1014-1018.

Haug, G.H., Hughen, K.A., Sigman, D.M., Peterson, L.C., Röhl, U., 2001. Southward migration of the Intertropical Convergence Zone through the Holocene. Science 293, 1304-1308.

Hendershott, M.C., Winnant, C.D., 1996. Surface circulation in the Santa Barbara Channel. Oceanography 9, 114-121.

Hendy, I.L., Kennett, J.P., 2000. Dansgaard/Oeschger Cycles and the California Current System: planktonic foraminiferal response to rapid climate change in the Santa Barbara Basin, California from 30-10 ka. Paleoceanography 15, 30-42.

Herbert, T.D., Yasuda, M., Burnett, C., 1995. Glacial-interglacial seasurface temperature record inferred from alkenone unsaturation indices, Site 893, Santa Barbara Basin. Proceedings of the Ocean Drilling Program. Scientific Results 146 (2), 257-264.

Hood, R.R., Abbott, M.R., Huyer, A., Kosro, P.M., 1999. Surface patterns in temperature, flow, phytoplankton biomass, and species composition in the coastal transition zone off northern California. Geophysical Research Letters 95 (C10), 18,018-18,094.

Huyer, A., 1983. Coastal upwelling in the California Current system. Progress in Oceanography 12, 259-284.

Kennett, J.P., Ingram, B.L., 1995. Paleoclimatic evolution of Santa Barbara Basin during the last 20 k.y.: marine evidence from Hole 893A. Proceedings of the Ocean Drilling Program. Scientific Results 146 (2), 309-325.

Kennett, J.P., Roark, E.B., Cannariato, K.G., Ingram, L., Tada, R., 2000. Latest Quaternary paleoclimatic and radiocarbon chronology, Hole 1017E, southern California margin. Proceedings of the Ocean Drilling Program, Scientific Results 167, 249-254.

Kiefer, T., Kienast, M., 2005. Patterns of deglacial warming in the Pacific Ocean: a review with emphasis on the time interval of Heinrich event I. Quaternary Science Reviews 24, 1063-1081.

Kim, J.-H., Timbu, N., Lorenz, S.J., Lohmann, G., Nam, S.I., Schouten, S., Rühlemann, C., Schneider, R.R., 2004. North Pacific and North Atlantic sea-surface temperature variability during the Holocene. Quaternary Science Reviews 23, 2141-2154.

Koutavas, A., Lynch-Stieglitz, J., Marchitto, T.M., Sachs, J.P., 2002. El Niño-like pattern in Ice Age tropical Pacific sea surface temperature. Science 297, 226-230.

Kreitz, S.F., Herbert, T.D., Schuffert, J.D., 2000. Alkenone paleothermometry and orbital-scale changes in sea-surface temperature at Site 1020, northern California margin. Proceedings of the Ocean Drilling Program. Scientific Results 167, 153-161.

Ling, H.Y., 1973. Silicoflagellates and ebridians from Leg 19. Initial Reports of the Deep Sea Drilling Project 19, 751-775.

Lopes, C., Mix, A., Abrantes, F., 2006. Diatoms in northeast Pacific surface sediments as paleoceanographic proxies. Marine Micropaleontology 60, 45-65.

Lyle, M., Mix, A.A., Ravelo, A.C., Andreasen, D., Heusser, L., Olivarez, A., 2000. Millennial-scale $\mathrm{CaCO}_{3}$ and $\mathrm{C}$ org events along the northern and central California margins: Stratigraphy and origins. Proceedings of the Ocean Drilling Program, Scientific Results 167, 163-182.

McCartney, K., Churchill, S., Woestendiek, L., 1995. Silicoflagellates and ebridians from Leg 138, Eastern Equatorial Pacific. Proceedings of the Ocean Drilling Program. Scientific Results 138, $129-162$ 
Mix, A.C., Lund, D.C., Pisias, N.G., Bodén, P., Bornmalm, L., Lyle, M., Pike, J., 1999. Rapid climate oscillations in the northeast Pacific during the last deglaciation reflect northern and southern hemisphere sources. In: Clark, P.U., Webb, R.S., Keigwin, L.D. (Eds.), Mechanisms for global climate change at millennial time scales. Geophysical Monograph', vol. 112. American Geophysical Union, Washington, DC, pp. 127-148.

Mortyn, P.G., Thunell, R.C., Anderson, D.M., Stott, L.D., Le, J., 1996. Sea surface temperature changes in the Southern California Borderlands during the last glacial-interglacial cycle. Paleoceanography $11,415-430$.

Onodera, J., Takahashi, K., 2005. Silicoflagellate fluxes and environmental variations in the northwestern Pacific during December 1997-May 2000. Deep-Sea Research II 52, 2218-2239.

Ortiz, J., Mix, A., Hostetler, S., Kashgarian, M., 1997. The California Current of the last glacial maximum: reconstruction at $42^{\circ} \mathrm{N}$ based on multiple proxies. Paleoceanography 12, 191-205.

Pak, D.K., Lea, D.W., Kennett, J.P., 2004. Seasonal and interannual variation in Santa Barbara Basin water temperatures observed in sediment trap foraminiferal $\mathrm{Mg} / \mathrm{Ca}$. Geochemistry, Geophysics, Geosystems 5 (12), 1-18.

Patterson, D.T., Prokoph, A., Wright, C., Chang, A.S., Thomson, R.E., Ware, D.M., 2004. Holocene solar variability and pelagic fish productivity in the NE Pacific. Palaeontologia Electronica 7 (4), 1-17 (http://palaeo-electronica.org/paleo/2004_3/fish2/issue1_04. $\mathrm{htm})$.

Pisias, N.G., A. Mix, A.C., Heusser, L., 2001. Millennial scale climate variability of the Northeast Pacific Ocean and Northwest North America based on Radiolaria and pollen. Quaternary Science Reviews 20, 1561-1576.

Poelchau, H.S., 1976. Distribution of Holocene silicoflagellates in North Pacific sediments. Micropaleontology 22, 164-193.

Prahl, F.G., Pisias, N., Sparrow, M.A., Sabin, A., 1995. Assessment of sea-surface temperature at $42^{\circ} \mathrm{N}$ in the California Current over the last 30,000 years. Paleoceanography 10 (4), 763-773.

Sabin, A.L., Pisias, N.G., 1996. Sea surface temperature changes in the northeastern Pacific Ocean during the past 20,000 years and their relationship to climate in northwestern North America. Quaternary Research 46, 48-61.

Sancetta, C., 1992. Comparison of phytoplankton in sediment trap time series and surface sediments along a productivity gradient Paleoceanography 7, 183-194.

Sandweiss, D.H., Maasch, K.A., Burger, R.L., Richardson III, J.B., Rollins, H.B., Clement, A., 2001. Variation in Holocene El Niño frequencies: climate records and cultural consequences in ancient Peru. Geology 29, 603-606.

Schrader, H.-J., Gersonde, R., 1978. Diatoms and silicoflagellates. Utrecht Micropaleontology Bulletin 17, 129-176.

Seki, O., Ishiwatari, R., Matsumoto, K., 2002. Millennial climate oscillations in NE Pacific surface waters over the last 82 kyr: New evidence from alkenones. Geophysical Research Letters 29, 2144. doi:10.1029/2002GL015200.

Strub, P.T., Allen, J.S., Huyer, A., Smith, R.L., Beardsley, R.C., 1987. Seasonal cycles of currents, temperatures, winds, and sea level over the northeast Pacific continental shelf. Journal of Geophysical Research 92 (C2), 507-1526.

Takahashi, K., 1987. Seasonal fluxes of silicoflagellates and Actiniscus in the subarctic Pacific during 1982-1984. Journal of Marine Research 45, 397-425.

Takahashi, K., Honjo, S., Tabata, S., 1989. Siliceous phytoplankton flux: interannual variability and response to hydrographic changes in the northeastern Pacific. In: Peterson, D. (Ed.), Aspects of Climate Variability in the Pacific and Western Americas. Geophysical Monograph, vol. 55. American Geophysical Union, Washington, DC, pp. $151-160$.

Tudhope, A.W., Chilcott, C.P., McCulloch, M.T., Cook, E.R., Chappell, J., Ellam, R.M., Lea, D.W., Lough, J.M., Shimmield, G.B., 2001. Variability in the El Niño-Southern Oscillation through a glacial-interglacial cycle. Science 291, 1511-1517.

Ujiié, Y., Ujiié, H., Taira, A., Nakamura, T., Nakamura, T., 2003. Spatial and temporal variability of surface water in the Kuroshio source region, Pacific Ocean, over the past 21,000 years: evidence from planktonic foraminifera. Marine Micropaleontology 49, $335-364$. 